\title{
Role of the Adrenergic System in a Mouse Model of Oxygen-Induced Retinopathy: Antiangiogenic Effects of $\beta$-Adrenoreceptor Blockade
}

\author{
Chiara Ristori, ${ }^{1}$ Luca Filippi, ${ }^{2}$ Massimo Dal Monte, ${ }^{1}$ Davide Martini, ${ }^{1}$ \\ Maurizio Cammalleri, ${ }^{1}$ Pina Fortunato, ${ }^{3}$ Giancarlo la Marca, ${ }^{4}$ Patrizio Fiorini, ${ }^{2}$ \\ and Paola Bagnoli ${ }^{1}$
}

Purpose. Oxygen-induced retinopathy (OIR) is a model for human retinopathy of prematurity (ROP). In OIR mice, this study determined whether blockade of $\beta$-adrenergic receptors ( $\beta$-ARs) with propranolol influences retinal levels of proangiogenic factors, retinal vascularization, and blood-retinal barrier (BRB) breakdown.

Methods. Propranolol was administered subcutaneously and picropodophyllin (PPP) intraperitoneally. Intravitreal injections of vascular endothelial growth factor (VEGF) were performed. Messengers of $\beta$-ARs, VEGF, its receptors, IGF- 1 and IGF-1R were measured with quantitative RT-PCR. VEGF content was determined with ELISA. $\beta$-ARs, hypoxia-inducible factor (HIF)- $1 \alpha$, occludin, and albumin were measured with Western blot. Retinal localization of $\beta 3$-ARs was determined by immunohistochemistry. Retinopathy was assessed by scoring fluorescein-perfused retinas, and plasma extravasation was visualized by Evans blue dye.

Results. Hypoxia did not influence $\beta$-AR expression, except that it increased $\beta 3$-AR protein with dense $\beta 3$-AR immunoreactivity localized to engorged retinal tufts. Hypoxia upregulated VEGF, IGF-1, their receptors, and HIF-1 $\alpha$. Propranolol dose-dependently reduced upregulated VEGF and decreased hypoxic levels of IGF-1 mRNA and HIF- $1 \alpha$. Blockade of IGF-1R activity with PPP did not influence propranolol's effects on VEGF. Retinal VEGF in normoxic mice or VEGF in brain, lungs, and heart of the OIR mice were unaffected by propranolol. Propranolol ameliorated the retinopathy score, restored occludin and albumin, and reduced hypoxia-induced plasma extravasation without influencing the vascular permeability induced by intravitreal VEGF.

Conclusions. This is the first demonstration that $\beta$-AR blockade is protective against retinal angiogenesis and ameliorates BRB dysfunction in OIR. Although the relevance of these results to

From the ${ }^{1}$ Department of Biology, University of Pisa, Pisa, Italy; the ${ }^{2}$ Neonatal Intensive Care Unit, Department of Critical Care Medicine, "A. Meyer" University Children's Hospital, Florence, Florence, Italy; and the Departments of ${ }^{3}$ Surgical Oto-Neuro-Ophthalmology Sciences and ${ }^{4} \mathrm{Pharmacology}$, University of Florence, Florence, Italy.

Supported by the Meyer Foundation, "A. Meyer" University Children's Hospital, and the Foundation of the Cassa di Risparmi of Livorno (PB).

Submitted for publication March 16, 2010; revised July 6, 2010; accepted July 20, 2010.

Disclosure: C. Ristori, None; L. Filippi, None; M. Dal Monte, None; D. Martini, None; M. Cammalleri, None; P. Fortunato, None; G. la Marca, None; P. Fiorini, None; P. Bagnoli, None

Corresponding author: Paola Bagnoli, Dipartimento di Biologia, Università di Pisa, Via San Zeno, 31, 56127 Pisa, Italy; pbagnoli@biologia.unipi.it. infant ROP is uncertain, the findings may help to establish potential pharmacologic targets based on $\beta 3$-AR pharmacology. (Invest Ophthalmol Vis Sci. 2011;52:155-170) DOI:10.1167/ iovs. 10-5536

$\mathrm{A}$ s understanding of the heterogeneous pathophysiology of retinopathy of prematurity (ROP) has increased, emphasis has shifted to more selective therapy that targets components of the angiogenesis cascade. In this respect, increasing knowledge of factors regulating retinal neoangiogenesis mostly originates from work in animal models of oxygen-induced retinopathy (OIR). Indeed, OIR is characterized by the abnormal formation of new blood vessels which is similar to ROP. ${ }^{1}$

In the retina, the hypoxic condition increases the stability of the inducible subunit of the transcription factor hypoxia-inducible factor (HIF), HIF- $1 \alpha{ }^{2}$ HIF- $1 \alpha$ accumulation leads to the subsequent transactivation of HIF which, in turn, upregulates the expression of a variety of genes, including angiogenic growth factors. ${ }^{3}$ Of them, vascular endothelial growth factor (VEGF), insulin-like growth factor (IGF)-1, and their receptors are involved in the pathologic blood vessel formation that characterizes OIR and other proliferative retinopathies. ${ }^{1,4}$ In particular, IGF-1 is critical in normal retinal vascular development, and a lack of IGF-1 in the early neonatal period is associated with the lack of vascular growth and proliferative ROP. ${ }^{1}$ In this respect, IGF-1 has been demonstrated to increase the stability of HIF-1 $\alpha$ and its transcriptional activity ${ }^{5}$ and is a potent inducer of VEGF. ${ }^{6,7}$

VEGF overexpression in the hypoxic retina causes a breakdown in the blood-retinal barrier (BRB), ${ }^{8}$ probably due to downregulation of the tight junction protein occludin. ${ }^{9}$ The decrease in occludin, in turn, results in the leakage of albumin from many of the retinal blood vessels ${ }^{10}$ and in plasma extravasation that can be visualized with increased leakage of Evans blue, a dye that binds to serum proteins. ${ }^{11}$ In several species, intravitreal VEGF injection can mimic some of the features observed in OIR. In particular, intravitreal injection of VEGF causes severe breakdown of the BRB that results in plasma extravasation. ${ }^{12,13}$

In several systems, hypoxia has been shown to cause catecholaminergic overstimulation that in turn alters signaling pathways associated with $\beta$-adrenergic receptors $\left(\beta\right.$-ARs) ${ }^{14}$ Although $\beta$-AR expression in the retina has been established, ${ }^{15}$ little is known about $\beta$-AR localization. ${ }^{16,17}$

There is some evidence that angiogenesis is controlled by the adrenergic system through its regulation of proangiogenic factors. Most of the evidence originates from solid tumors and tumor cell lines, in which norepinephrine (NE) affects tumor progression by upregulating VEGF. ${ }^{18,19}$ In addition, in human umbilical vein endothelial cells, NE stimulates the production 
of VEGF. ${ }^{20}$ Finally, in neonatal rat cardiac myocytes, NE stimulates angiogenesis by upregulating VEGF. ${ }^{21}$

Whether angiogenesis regulation by the adrenergic system in the retina is mediated by $\beta$-AR modulation of proangiogenic factors remains to be clarified. There are reports of proliferation and migration of human retinal endothelial cells stimulated by $\beta 3$-AR activation. ${ }^{22}$ In addition, in human choroidal endothelial cells, the $\beta$-AR agonist isoproterenol leads to increased levels of growth factors implicated in ocular diseases. ${ }^{23}$ On the other hand, isoproterenol has been shown to inhibit diabeticlike changes in the rat retina, suggesting that loss of $\beta$-AR signaling may be a key factor in early diabetic retinopathy (DR) ${ }^{24}$ In line with these findings, propranolol, a $\beta$-AR nonselective antagonist, produces a dysfunctional electroretinogram (ERG) that occurs with an increase in IGF-1R phosphorylation and activation of VEGF in the rat retina. ${ }^{25}$ In rats with DR, propranolol does not affect retinal levels of VEGF, ${ }^{26}$ whereas a decrease in VEGF has been observed in the retinas of OIR rats, in which a reduction of the intraocular pressure by the $\beta$-AR antagonist timolol diminishes the severity of OIR. ${ }^{27}$

The effect of propranolol on ROP has not been studied so far. Recent results have demonstrated the efficacy of propranolol against infantile capillary hemangioma, even though there is no generally accepted concept of how propranolol actually works in infantile hemangioma. ${ }^{28}$ There are also findings indicating that infantile hemangiomas are associated with the development of ROP in preterm infants. ${ }^{29}$

In the present study, we investigated the role of propranolol in the regulation of retinal angiogenesis and vascular permeability. In particular, we determined whether propranolol affects retinal levels of proangiogenic factors, vascular leakage, and retinal neovascularization in a mouse model of OIR. The mechanisms of action of propranolol on angiogenesis were also investigated.

\section{Materials ANd Methods}

The PCR master mix (iQ SYBR Green Supermix) was from Bio-Rad (Hercules, CA). Primers were obtained from MWG Biotech (Ebersberg, Germany). A nucleic acid gel stain (GelStar) was from Cambrex (East Rutherford, NJ). The rabbit polyclonal antibodies against $\beta 1$ - and $\beta 2$ $\mathrm{AR}$; the goat polyclonal antibody directed to $\beta 3$-AR, its blocking peptide for preadsorbtion experiments; the goat IgG negative control; the mouse monoclonal antibody against HIF-1 $\alpha$; picropodophyllin (PPP), an inhibitor of IGF-1R phosphorylation; the goat polyclonal antibody directed to albumin; and the rabbit anti-goat horseradish peroxidaselabeled antibody were purchased from Santa Cruz Biotechnology (Santa Cruz, CA). The rabbit polyclonal antibody directed to occludin was obtained from Zymed Laboratory (South San Francisco, CA). The secondary antibody Alexa Fluor 488 was from Molecular Probes (Eugene, OR). The mouse anti-rabbit horseradish peroxidase-labeled antibody was obtained from Cell Signaling Technology (Beverly, MA). The enzyme-linked immunosorbent assay for the detection of VEGF (Quantikine Mouse VEGF ELISA kit) and the human recombinant VEGF $_{165}$ were obtained from R\&D Systems (Minneapolis, MN). The enhanced chemiluminescence reagent (WBKLS0500) was from Millipore (Billerica, MA). All other chemicals were obtained from SigmaAldrich (St. Louis, MO).

\section{Animals}

Experiments were performed on $205 \mathrm{C} 57 \mathrm{BL} / 6$ mice of both sexes at postnatal day (PD)17 (6 g body weight). In some experiments, mice at PD12 and -14 were also used (12 animals for each age). Experiments were performed in agreement with the ARVO Statement for the Use of Animals in Ophthalmic and Vision Research and in compliance with the Italian law on animal care No. 116/1992 and the EEC/609/86. All efforts were made to reduce the number of animals used.

\section{Model of Oxygen-Induced Retinopathy}

In a typical model of OIR, ${ }^{30}$ litters of mice pups with their nursing mothers were exposed in an infant incubator to high oxygen concentration $(75 \% \pm 2 \%)$ between $\mathrm{PD} 7$ and -12 , before return to room air between PD12 and -17 . Oxygen was checked twice daily with an oxygen analyzer (Miniox I; Bertocchi srl Elettromedicali, Cremona, Italy). Individual litters were either oxygen or room air reared. Pharmacologic treatments were performed in animals anesthetized by i.p. injection of Avertin (1.2\% tribromoethanol and 2.4\% amylene hydrate in distilled water, $0.02 \mathrm{~mL} / \mathrm{g}$ body weight). All experiments were performed at the same time of day, to exclude possible circadian influences. The data were collected from both males and females and the results combined, as there was no apparent difference between the sexes.

\section{Administration of Propranolol}

The nonselective $\beta$-AR antagonist propranolol was given subcutaneously three times a day from PD12 to -16 . Propranolol was used at concentrations ranging from 0.02 to $20 \mathrm{mg} \mathrm{kg}^{-1}$ dose $^{-1}$ and was dissolved in citrate buffer. Sham injections were performed with that vehicle. Intraperitoneal administration of propranolol at $20 \mathrm{mg} \mathrm{kg}^{-1}$ dose $^{-1}$ was also performed. Its effect on VEGF messenger was not significantly different from that obtained with propranolol administered subcutaneously (data not shown).

\section{Administration of IGF-1 Receptor Antagonist}

To examine the involvement of IGF-1 in propranolol-induced effects on hypoxic levels of VEGF, we used PPP, in agreement with previous studies. ${ }^{6}$ PPP is a small molecule belonging to the cyclolignan family, which inhibits phosphorylation of IGF-1R, ${ }^{31}$ known to mediate the proangiogenic effects IGF-1. ${ }^{32}$ OIR mice untreated or treated with propranolol from PD12 to $-16\left(20 \mathrm{mg} \mathrm{kg}^{-1}\right.$ dose $\left.^{-1}\right)$ received $20 \mathrm{mg}$ $\mathrm{kg}^{-1}$ i.p. injections of PPP in a $10-\mu \mathrm{L}$ volume of DMSO two times a day from PD12 to -16. Sham injections were performed with that vehicle. At PD17, the retinas were analyzed for VEGF mRNA and protein expression.

\section{Intravitreal Injection of VEGF}

Animals were anesthetized by i.p. injection of Avertin. At PD13, recombinant human $\mathrm{VEGF}_{165}(100 \mathrm{ng} / 1 \mu \mathrm{L})$ was injected into one eye, and an equal volume of vehicle (sterile phosphate buffered saline [PBS] with $0.025 \%$ bovine serum albumin [BSA]) wash injected into the other eye. Injections were performed with a 31-gauge needle (Hamilton, Reno, NV) through the corneal limbus into the vitreous cavity. Insertion and infusion were directly viewed through an operating microscope to prevent injury to the lens and retina. Propranolol $(20 \mathrm{mg}$ $\mathrm{kg}^{-1}$ ) was administered subcutaneously three times a day from PD12 to -16. At PD17 retinas were analyzed for blood-retinal vascular leakage by using Evans blue dye.

\section{Isolation of RNA and cDNA Preparation}

After death, the tissues were rapidly dissected, immediately frozen in liquid nitrogen, and stored at $-80^{\circ} \mathrm{C}$ until analysis. Total RNA was extracted (RNeasy Mini Kit; Qiagen, Valencia, CA), purified, resuspended in RNase-free water and quantified spectrophotometrically (SmartSpec 3000; Bio-Rad). First-strand cDNA was generated from $1 \mu \mathrm{g}$ of total RNA (QuantiTect Reverse Transcription Kit; Qiagen).

\section{Real-Time Quantitative RT-PCR}

Quantitative real-time RT-PCR (QPCR) was performed according to Dal Monte et al. ${ }^{33}$ QPCR primer sets were designed with Primer3 software $\left(\beta 3\right.$-AR, VEGFR-1, VEGFR-2, and IGF-1) ${ }^{34}$ or were obtained from either Primer Bank ( $\beta 1$-AR, $\beta 2$-AR, VEGF and IGF-1R) ${ }^{35}$ or RTPrimerDB (Rpl13a). ${ }^{36}$ Forward and reverse primers were chosen to hybridize to unique regions of the appropriate gene sequence; their sequences are listed in Table 1. Amplification efficiency was close to $100 \%$ for each 
primer pair (Opticon Monitor 3 software; Bio-Rad). Each target gene was run concurrently with Rpl13a, a constitutively expressed control gene. Samples were compared by using the relative threshold cycle $\left(C_{t}\right.$ method). ${ }^{37}$ The increase or decrease ( $x$-fold) was determined relative to a control after normalizing to Rp113a. All reactions were run in triplicate. After statistical analysis, the data from the different experiments were plotted and averaged in the same graph. Data are expressed as the mean $\pm \mathrm{SE}$ and originated from four samples for each experimental condition. Samples refer to the mRNA extracted from retina (two retinas for each sample) or brain, lung, or heart (20-30 mg of tissue for each sample).

\section{Enzyme-linked Immunosorbent Assay}

The VEGF protein concentration in tissue lysates was determined by ELISA. The measurement was performed on five samples for each experimental condition. Samples refer to the protein extracted from retina (two retinas for each sample) or brain, lung, or heart (30-40 mg of tissues for each sample). Samples were placed in $10 \mathrm{mM}$ Tris-HCl (pH 7.6) containing $5 \mathrm{mM}$ EDTA, $3 \mathrm{mM}$ EGTA, $250 \mathrm{mM}$ sucrose, $1 \mathrm{mM}$ phenylmethylsulfonyl fluoride, $1 \mu \mathrm{M}$ peptistatin, $10 \mu \mathrm{g} / \mathrm{mL}$ leupeptin, and $2 \mu \mathrm{g} / \mathrm{mL}$ aprotinin, and sonicated for 30 seconds at $50 \mathrm{~Hz}$. Retinal samples were lysed in $200 \mu \mathrm{L}$ buffer, and nonretinal samples were lysed in $500 \mu \mathrm{L}$ buffer. The lysates were centrifuged at 22,000 $\mathrm{g}$ for 15 minutes at $4{ }^{\circ} \mathrm{C}$. Protein concentration was determined according to Bradford $^{38}$ with BSA used as a standard. VEGF concentration was determined spectrophotometrically (Microplate Reader 680 XR; BioRad) at $450 \mathrm{~nm}$ (correction wavelength set at $570 \mathrm{~nm}$ ). In each experiment, all samples and standards were measured in duplicate. Data were collected as picograms VEGF per milligram total protein and, after statistical analysis, were averaged in the same graph.

\section{Western Blot Analysis}

Mice were deeply anesthetized with Avertin. The chest was opened, a catheter was inserted into the left ventricle, and a small incision was made in the right atrium. One hundred milliliters of $0.15 \mathrm{M}$ phosphate buffer (PB) were infused until the blood ran clear. Then the mice were killed, the eyes enucleated, and the retinas dissected. Western blot analysis was performed on proteins extracted from three samples (each containing four retinas) for each experimental condition. Briefly, the retinas were homogenized in $10 \mathrm{mM}$ Tris- $\mathrm{HCl}(\mathrm{pH}$ 7.6) containing $5 \mathrm{mM}$ EDTA, $3 \mathrm{mM}$ EGTA, $250 \mathrm{mM}$ sucrose, $1 \mathrm{mM}$ phenylmethylsulfonyl fluoride, $1 \mu \mathrm{M}$ peptistatin, $10 \mu \mathrm{g} / \mathrm{mL}$ leupeptin, and $2 \mu \mathrm{g} / \mathrm{mL}$ aprotinin and centrifuged at $22,000 \mathrm{~g}$ for 30 minutes at $4^{\circ} \mathrm{C}$. The supernatant was used for HIF1- $\alpha$ or albumin detection. The pellet was resuspended in $20 \mathrm{mM}$ HEPES (pH 7.4) containing $150 \mathrm{mM} \mathrm{NaCl}, 5 \mathrm{mM}$ EDTA, $3 \mathrm{mM}$ EGTA, $4 \mathrm{mg} n$-dodecyl- $\beta$-maltoside, $1 \mathrm{mM}$ phenylmethylsulfonyl fluoride, $1 \mu \mathrm{M}$ peptistatin, $10 \mu \mathrm{g} / \mathrm{mL}$ leupeptin, and $2 \mu \mathrm{g} / \mathrm{mL}$ aprotinin, and centrifuged at $22,000 \mathrm{~g}$ for 30 minutes at $4^{\circ} \mathrm{C}$. The supernatant was used for $\beta$-AR or occludin detection. Protein concentration was measured according to Bradford ${ }^{38}$ with BSA used as a standard. Forty micrograms of protein were resolved by SDS-PAGE and then blotted onto polyvinylidene difluoride membrane. Specific antibodies directed to distinct $\beta$-ARs (1:200 dilution), HIF-1 $\alpha$ (1:100 dilution), occludin (1:250 dilution), and albumin (1:100 dilution) were used in agreement with previous studies. ${ }^{2,10,39}$ The same membrane was reblotted with an anti- $\beta$-actin antibody $(1: 2,500)$ as the loading control. Mouse anti-rabbit horseradish peroxidase-labeled (1:5,000 dilution), rabbit anti-goat horseradish peroxidase-labeled (1:1,000 dilution), or rabbit anti-mouse horseradish-peroxidase-labeled (1:25,000 dilution) were used as secondary antibodies. Blots were developed with the enhanced chemiluminescence reagent, and were stripped between each assay. The optical density (OD) of the bands was evaluated (Quantity One software; Bio-Rad). The data were normalized to the level of $\beta 3$-actin. All experiments were run in duplicate. The semiquantitative analysis of Western blot signals was based on three independent blot analysis experiments. After statistical analysis, data from the different experiments were plotted and averaged in the same graph.

\section{Immunohistochemistry}

Retinal whole mounts were fixed for 1.5 hours in $4 \%$ paraformaldehyde in $0.1 \mathrm{M} \mathrm{PB}$ at $4^{\circ} \mathrm{C}$. The fixed retinas were transferred to $25 \%$ sucrose in $0.1 \mathrm{M} \mathrm{PB}$ and stored at $4^{\circ} \mathrm{C}$. They were rinsed in $0.1 \mathrm{M} \mathrm{PB}$ and incubated for 72 hours at $4^{\circ} \mathrm{C}$ in the $\beta 3$-AR goat polyclonal antibody directed against the mouse $\mathrm{C}$ terminus (1:200). Triton X-100 at $1 \%$ was added to the antibody diluted in $0.1 \mathrm{M} \mathrm{PB}$ at 1:100 (final concentration, $1 \mu \mathrm{g} / \mathrm{mL}$ ). After incubation, the whole mounts were rinsed in $0.1 \mathrm{M} \mathrm{PB}$ and incubated overnight at $4^{\circ} \mathrm{C}$ in Alexa Fluor 488 at a dilution of $1: 200$ in $0.1 \mathrm{M} \mathrm{PB}$ containing $0.5 \%$ Triton X-100. Finally, they were rinsed in $0.1 \mathrm{M} \mathrm{PB}$, mounted on gelatin-coated glass slides, and coverslipped with a $0.1-\mathrm{M}$ PB-glycerine mixture. The specificity of the goat $\beta 3$-AR antibody was evaluated by the use of preimmune serum instead of the primary antibody, by preadsorption with the corresponding blocking peptide $(3-5 \mu \mathrm{g} / \mathrm{mL})$ and by the use of goat IgG negative control $(1 \mu \mathrm{g} / \mathrm{mL})$ instead of the primary antibody. Immunofluorescent materials were observed with confocal microscopy (Laser Scanning Microscope Radiance Plus; Bio-Rad) with a $\times 20$ objective lens. Serial optical sections ( $1 \mu \mathrm{m}$ apart) were scanned

TABLe 1. Primers Used for PCR Analysis

\begin{tabular}{|c|c|c|c|}
\hline Gene & Primer Sequence & $\begin{array}{c}\text { Product } \\
\text { Length }(b p)\end{array}$ & $\begin{array}{c}\text { Gene Bank } \\
\text { Accession No. }\end{array}$ \\
\hline$\beta 1-A R$ & $\begin{array}{l}\text { Forward: CTCATCGTGGTGGGTAACGTG } \\
\text { Reverse: ACACACAGCACATCTACCGAA }\end{array}$ & 215 & NM_007419 \\
\hline$\beta 2-A R$ & $\begin{array}{l}\text { Forward: GGGAACGACAGCGACTTCTT } \\
\text { Reverse: GCCAGGACGATAACCGACAT }\end{array}$ & 125 & NM_007420 \\
\hline$\beta 3-A R$ & $\begin{array}{l}\text { Forward: CGCTACCTAGCTGTCACCAA } \\
\text { Reverse: TAGAAGGAGACGGAGGAGGA }\end{array}$ & 239 & NM_013462 \\
\hline$V E G F$ & $\begin{array}{l}\text { Forward: GCACATAGGAGAGATGAGCTTCC } \\
\text { Reverse: CTCCGCTCTGAACAAGGCT }\end{array}$ & 105 & NM_009505 \\
\hline$V E G F R-1$ & $\begin{array}{l}\text { Forward: GAGGAGGATGAGGGTGTCTATAGGT } \\
\text { Reverse: GTGATCAGCTCCAGGTTTGACTT }\end{array}$ & 116 & NM_010228 \\
\hline VEGFR-2 & $\begin{array}{l}\text { Forward: GCCCTGCTGTGGTCTCACTAC } \\
\text { Reverse: CAAAGCATTGCCCATTCGAT }\end{array}$ & 114 & NM_010612 \\
\hline$I G F-1$ & $\begin{array}{l}\text { Forward: TTCAGTTCGTGTGTGGACCGAG } \\
\text { Reverse: TCCACAATGCCTGTCTGAGGTG }\end{array}$ & 94 & NM_010512 \\
\hline$I G F-1 R$ & $\begin{array}{l}\text { Forward: GTGGGGGCTCGTGTTTCTC } \\
\text { Reverse: GATCACCGTGCAGTTTTCCA }\end{array}$ & 127 & NM_010513 \\
\hline$R p 113 a$ & $\begin{array}{l}\text { Forward: CACTCTGGAGGAGAAACGGAAGG } \\
\text { Reverse: GCAGGCATGAGGCAAACAGTC }\end{array}$ & 182 & NM_009438 \\
\hline
\end{tabular}


TABLE 2. Retinopathy Scoring System

Points

\begin{tabular}{|c|c|c|c|c|c|}
\hline Criteria & $\mathbf{0}$ & 1 & 2 & 3 & 4 \\
\hline ressel tufts & None & In $<3$ clock hours & In 3-5 clock hours & In 6-8 clock hours & In $9-12$ clock hours \\
\hline ll avascular area & None & $\begin{array}{l}\text { Mild, early zone } 1 \\
\text { (inner } 50 \% \text { of } \\
\text { zone 1) }\end{array}$ & $\begin{array}{l}\text { Moderate, throughout } \\
\text { zone } 1 \text { (outer } 50 \% \\
\text { of zone 1) }\end{array}$ & $\begin{array}{l}\text { Severe, extending } \\
\text { to zone } 2\end{array}$ & - \\
\hline $\begin{array}{l}\text { ned extraretinal } \\
\text { vascularization }\end{array}$ & None & In $<3$ clock hours & In 3-6 clock hours & In $>6$ clock hours & - \\
\hline 1 hemorrhage & Absent & Present & - & - & \\
\hline vessel tortuosity & None & $<1 / 3$ of vessels & $1 / 32^{-2 / 3}$ of vessels & $>2 / 3$ of vessels & - \\
\hline
\end{tabular}

Flat-mounted retinas were examined by fluorescence microscopy, and retinopathy was quantified by evaluating five criteria. Points received for each criterion were summed, to obtain the retinopathy score. A higher score (range, 0-14) indicates more severe retinopathy. The scoring system was adapted from previously published protocols. ${ }^{33,40}$

through the thickness of each whole mount at the same predetermined $z$-axis. The digital images were sized and optimized for contrast and brightness with image-editing software (Photoshop; Adobe Systems, Mountain View, CA)

\section{Assessment of Retinal Vascularization}

Fluorescein-conjugated dextran perfusion of the retinal vessels was performed as previously described. ${ }^{33}$ Briefly, in anesthetized animals, a median sternotomy was performed, and the left ventricle was perfused with $2 \mathrm{~mL}$ of a $25-\mathrm{mg} / \mathrm{mL}$ solution of fluorescein-conjugated dextran in $0.15 \mathrm{M} \mathrm{PB}$. The eyes were enucleated, the retinas were dissected, and flat mounts were obtained and mounted in antifade medium (Vectashield; Vector Laboratories, Burlingame, CA), vitreous side up under coverslips. Whole mounts were viewed by fluorescence microscopy (Eclipse E800; Nikon, Badhoevedorp, The Netherlands) and images were acquired (DFC320 camera; Leica Microsystems, Wetzlar, Germany). Neovascularization was evaluated with a retinopathy scoring system that was adapted from published protocols (Table 2). ${ }^{33,40}$ Three trained observers evaluated the number of clock hours with abnormal vessels for each retina. The data were averaged and are expressed in values ranging from 0 to 14 .

\section{Measurement of Retinal Vascular Leakage}

The blood-retinal vascular leakage was evaluated using Evans blue dye as described in another study. ${ }^{11}$ After the mice were deeply anesthetized with Avertin, Evans blue dye, dissolved in normal saline (30 $\mathrm{mg} / \mathrm{mL}$ ), was injected through the femoral vein under microscopic inspection, according to Tomasek et al. ${ }^{41}$ Immediately after Evans blue infusion, the mice turned visibly blue, confirming their uptake and distribution of the dye. The mice were kept on a warm pad to ensure the complete circulation of the dye and were killed 2 hours after Evans blue infusion. The eyes were removed and immediately immersed in $2 \%$ paraformaldehyde. After 2 hours, the retinas were dissected, and flat mounts were obtained and mounted on glass slides. Retinal flat mounts were analyzed by fluorescence microscopy (Eclipse E800; Nikon) and images were acquired (DFC320 camera; Leica Microsystems, Bannockburn, IL).

\section{Statistical Analysis}

Retinopathy scores were evaluated with the Kruskal-Wallis test for the overall group and by the Dunn's post hoc test for differences between groups. Retinopathy score data are represented as the median (25th, 75 th quartiles). All other data were analyzed with the KolmogorovSmirnov test on verification of normal distribution. Statistical significance was evaluated with unpaired $t$-test or with ANOVA followed by the Newman-Keuls multiple-comparison test. The results are expressed as mean \pm SE of the indicated $n$ values (Prism; GraphPad Software, San Diego, CA). Differences with $P<0.05$ were considered significant

\section{Results}

\section{$\boldsymbol{\beta}$-ARs in the Retina}

We verified whether hypoxia affects messenger and protein expression of $\beta 1-\beta 2$, and $\beta 3$-ARs in the mouse retina. As shown in Figure 1A, the predicted length of each QPCR product was confirmed by agarose gel electrophoresis performed on mRNA extracted from normoxic retinas $(215,125,239$, and $182 \mathrm{bp}$ corresponding to the mRNA of $\beta 1-, \beta 2-$, and $\beta 3$-AR and Rpl13a). Five days of normoxia after hyperoxia (relative hypoxia) did not influence $\beta$-AR mRNAs, which were similar to those in control retinas. Semiquantitative Western blot demonstrated that hypoxic levels of $\beta 1$ - and $\beta 2$-ARs were not significantly different from control values, whereas retinal levels of $\beta 3$-ARs were significantly higher than those in control conditions $(\sim 122 \%, P<0.01$; Fig. $1 \mathrm{~B})$. As shown in Figure $1 \mathrm{C}, \beta 3$-AR levels were not significantly different from control values at both PD12 (end of the period of hyperoxia) and PD14 (2 days of normoxia), although a trend toward increased $\beta 3$-AR expression was observed at PD14.

Immunohistochemistry was performed to localize $\beta 3$-ARs to the mouse retina and to confirm the results of Western blot analysis. The antibody used in the present study has been used in other immunohistochemical studies. ${ }^{42,43}$ The specificity of immunoreactivity (IR) was evaluated with the use of preimmune serum instead of the primary antibody (data not shown) and preabsorption tests using control antigen peptides. An additional test for specificity of IR included the use of goat IgG negative control. The controls for immunohistochemistry resulted in the absence of IR as shown by the representative images in the inner capillary plexus of the mid-peripheral retina (Figs. $2 \mathrm{~A}-\mathrm{C}$ ). In the normoxic retina of the PD17 mice, $\beta 3$-AR-IR was found to be associated with both the outer and the inner capillary plexus (Fig. 3). Five days of normoxia after hyperoxia resulted in a dense $\beta 3$-AR-IR that was associated with engorged retinal tufts in the inner capillary plexus (Fig. 4).

\section{VEGF, VEGFR-1, VEGFR-2, IGF-1, and IGF-1R in the Retina}

We evaluated whether blockade of $\beta$-ARs with propranolol might be related to variations in retinal levels of VEGF or IGF-1, as well as their receptors, in the OIR model. In all experiments, no effects were detected after vehicle treatment.

VEGF, VEGF Receptor Messengers, and VEGF Protein. As shown in Figure $5 \mathrm{~A}$, the predicted length of each QPCR product was confirmed by agarose gel electrophoresis performed on mRNA extracted from normoxic retinas $(105,116$, 
A
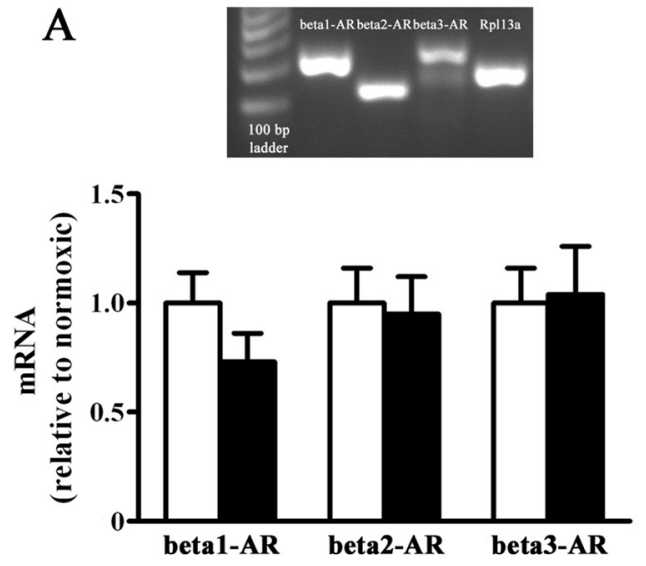

B
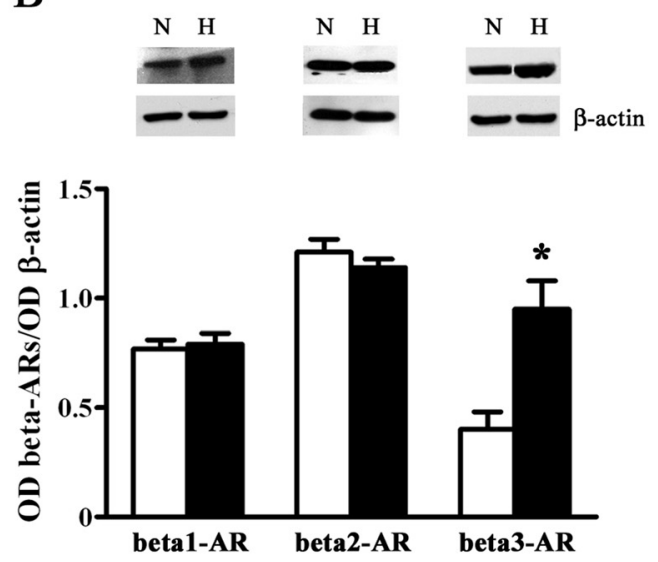

C
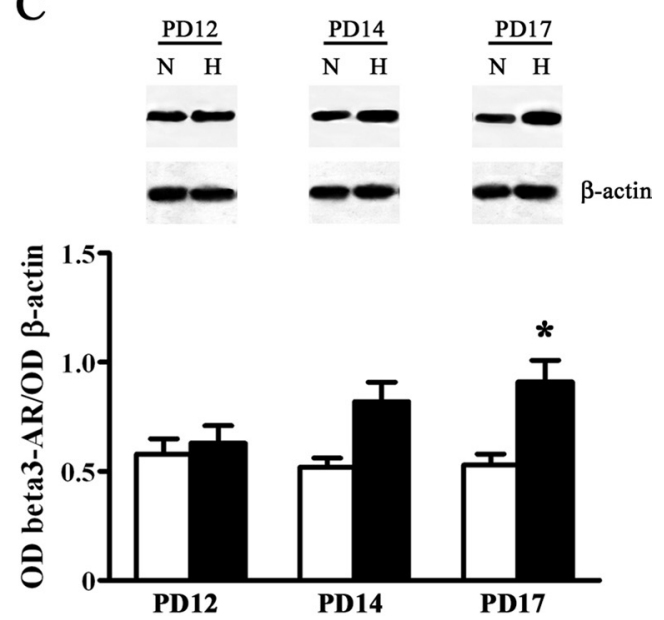

FIGURE 1. $\beta 1$-, $\beta 2$-, and $\beta 3$-ARs in mouse retinas. (A) The predicted length of each QPCR product was confirmed by agarose gel electrophoresis performed on mRNA extracted from control retinas (at 215, 125,239 , and $182 \mathrm{bp}$, corresponding to the mRNA of $\beta 1-, \beta 2-, \beta 3$-ARs, and Rpl13a). $\beta$-AR mRNAs in normoxic $(\square)$ and hypoxic ( $\square$ ) conditions are shown at PD17 which corresponds to 5 days of normoxia after hyperoxia. Data were analyzed by the $C_{t}$ method, with Rpl13a used as the internal standard. Each histogram represents the mean \pm SE of data from four samples. Each sample was the mRNA extracted from two retinas. (B) Protein levels of distinct $\beta$-ARs in normoxic ( $\square$ ) and hypoxic ( ) conditions, as evaluated by Western blot, with $\beta$-actin used as the loading control. Densitometric analysis showed that $\beta 3$-AR was increased by hypoxia at PD17 $\left(^{*} P<0.01\right.$ vs. the respective control; ANOVA followed by Newman-Keuls multiple-comparison post test). (C) No effects were observed at PD12, which corresponds
114, and $182 \mathrm{bp}$, corresponding to the mRNA of VEGF, VEGFR-1, VEGFR-2, and Rpl13a). In agreement with previous results, ${ }^{33,44}$ hypoxic retinas displayed significantly increased levels of VEGF, VEGFR-1, and VEGFR-2 mRNA (Figs. 5B-D, insets). As shown in Figure 5B, VEGF mRNA levels were reduced significantly by propranolol at either $2 \mathrm{mg} \mathrm{kg}^{-1}$ or 20 mg kg ${ }^{-1}(\sim 30 \%$ and $\sim 60 \%, P<0.05$ and $P<0.001$, respectively). In particular, the reduction of VEGF mRNA after propranolol at $20 \mathrm{mg} \mathrm{kg}^{-1}$ was significantly higher than that obtained with $2 \mathrm{mg} \mathrm{kg}^{-1}$ propranolol $(\sim 50 \%, P<0.01)$. In contrast, a dose of $0.02 \mathrm{mg} \mathrm{kg}^{-1}$ did not significantly influence VEGF messenger. As shown in Figures $5 \mathrm{C}$ and $5 \mathrm{D}$, propranolol at $20 \mathrm{mg} \mathrm{kg}^{-1}$ did not affect messengers of VEGF receptors. VEGF content in the retina was analyzed by ELISA. Hypoxic retinas displayed significantly increased levels of VEGF, as quantitated by ELISA (Fig. 6, inset). VEGF levels in both normoxic and hypoxic retinas are in the range of those measured in other studies of the rodent retina (for references see Ref. 33). As shown in Figure 6, a dose-dependent decrease of VEGF was observed after treatment with increasing concentrations of propranolol with no effects at $0.02 \mathrm{mg} \mathrm{kg}^{-1}$, a decrease at $2 \mathrm{mg}$ $\mathrm{kg}^{-1}(\sim 65 \%$ vs. the treatment with vehicle, $P<0.001)$ and a further reduction at $20 \mathrm{mg} \mathrm{kg}^{-1}(\sim 85 \%$ vs. the treatment with vehicle, $P<0.001$ and $\sim 60 \%$ vs. the treatment with propranolol at $2 \mathrm{mg} \mathrm{kg}^{-1}, P<0.001$ ). Neither VEGF mRNA nor VEGF content in the normoxic retina was influenced by propranolol at $20 \mathrm{mg} \mathrm{kg}^{-1}$ (Fig. 7).

To determine whether HIF- $1 \alpha$ is involved in the propranolol-induced inhibition of VEGF expression, we evaluated whether $\beta$-AR blockade is related to variations in retinal levels of HIF- $1 \alpha$ in the OIR model. As shown in Figure 8, the retinal expression of HIF- $1 \alpha$ significantly increased in the OIR mice ( $\sim$ 7.5-fold), compared with control littermates $(P<0.001)$. Vehicle administration did not alter hypoxic levels of HIF-1 $\alpha$, whereas treatment with propranolol at $20 \mathrm{mg} \mathrm{kg}^{-1}$ partially restored retinal HIF- $1 \alpha$ expression by decreasing its level to $\sim 50 \%$ of that in the vehicle-treated mice $(P<0.001)$. HIF- $1 \alpha$ level after propranolol was higher than the respective normoxia-exposed group (" $P<0.01$; ANOVA).

IGF-1 and IGF-1 Receptor Messengers. As shown in Figure 9A, the predicted length of each QPCR product was confirmed by agarose gel electrophoresis $(94,127$, and $182 \mathrm{bp}$ corresponding to the mRNA of IGF-1, IGF-1R, and Rpl13a). Hypoxic retinas displayed increased levels of both IGF-1 and IGF-1R ( $\sim 70 \%$ and $\sim 50 \%$, respectively, $P<0.05$; Fig. 9B). Normoxic levels of both IGF-1 and IGF-1R were unaffected by propranolol at $20 \mathrm{mg} \mathrm{kg}^{-1}$ (data not shown). Propranolol at 20 $\mathrm{mg} \mathrm{kg}^{-1}$ significantly decreased levels of IGF-1 mRNA ( $\sim 45 \%$, $P<0.05$ ), whereas it did not affect IGF-1R messenger (Figs. 9C, 9D).

IGF-1 and VEGF. Since propranolol reduced both VEGF and IGF-1 expression and IGF-1 per se is a potent inducer of VEGF, ${ }^{6,7}$ we determined whether these events were in parallel or were causal by using PPP, which inhibits phosphorylation of IGF-1R and blocks its downstream signaling. ${ }^{31}$ The OIR mice were treated with vehicle or PPP $\left(20 \mathrm{mg} \mathrm{kg}^{-1}\right)$, either alone or in combination with propranolol at $20 \mathrm{mg} \mathrm{kg}^{-1}$. We observed that neither vehicle nor PPP administration affected the hypoxic levels of VEGF mRNA and protein, which were not significantly different from those measured in untreated animals. We also observed that VEGF mRNA and protein expres-

to the end of hyperoxia, or at PD14 which corresponds to 2 days of normoxia after hyperoxia. Each histogram represents the mean \pm SE of data from three samples. Each sample was the protein extracted from five retinas. Representative gels are also shown. N, normoxia; $H$, hypoxia. 

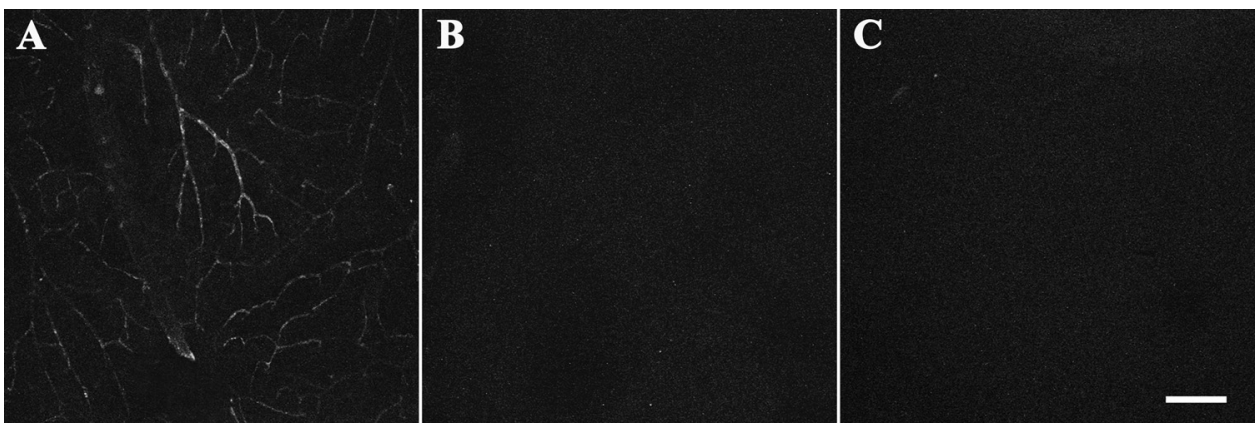

Figure 2. Specificity evaluation of the goat polyclonal antibody directed to $\beta 3$ ARs. Representative confocal images from mouse retinal whole mounts scanned at the level of the inner capillary plexus with a $\times 20$ objective. These images are representative of the results obtained in three whole mounts incubated with the goat polyclonal anti- $\beta 3$-ARs (A), with the blocking peptide solution (B), and in the presence of goat IgG negative control instead of the primary antibody (C). Scale bar, $100 \mu \mathrm{m}$.

sion in the $\mathrm{PPP}+$ propranolol-treated animals was not significantly different from that in the vehicle+propranolol-treated animals (Fig. 10).

VEGF Messenger and Protein in the Brain, Lungs, and Heart. We evaluated whether propranolol at $20 \mathrm{mg} \mathrm{kg}^{-1}$ influences VEGF levels in either the brain or those organs, such as lungs and heart, that are known to be targeted by $\beta$ blockers. ${ }^{45-47}$ As shown in Figures 11A, 11C, and 11E, hypoxia did not affect VEGF mRNA in brain, lungs, or heart. In neither normoxic nor hypoxic conditions were VEGF mRNA levels influenced by propranolol at $20 \mathrm{mg} \mathrm{kg}^{-1}$. Protein determination confirmed the messenger data. In fact, none of the organs studied showed any effects of propranolol on VEGF protein, as quantitated by ELISA (Figs. 11B, 11D, 11F).

\section{Retinal Neovascularization}

To investigate whether propranolol can reduce retinal neovascularization, we treated the OIR mice with propranolol at 20 $\mathrm{mg} \mathrm{kg}^{-1}$ and qualitatively and quantitatively analyzed propranolol's effect on retinal neovascularization. To investigate the antiangiogenic activity of propranolol on retinal neovascularization in OIR, we performed fluorescence angiography. Figure 12 shows the vascular pattern of flat mounts under normoxic (Fig. 12A) and hypoxic (Fig. 12B) conditions, and after the administration of either vehicle (Fig. 12C) or propranolol at $20 \mathrm{mg} \mathrm{kg}^{-1}$ (Fig. 12D) to the hypoxic mice. In agreement with previous results, ${ }^{30}$ exposure to $75 \% \pm 2 \%$ oxygen between PD 7 and -12 resulted in the disappearance of existing capillaries in the central retina, although the peripheral retina remained vascularized. Recovery in room air until PD17 allowed incomplete revascularization of the central avascular portion with associated marked neovascularization at the border between the central avascular and peripheral vascularized retina including the formation of engorged vessel tufts extending into the vitreous. Both vessel tufts and retinal hemorrhages
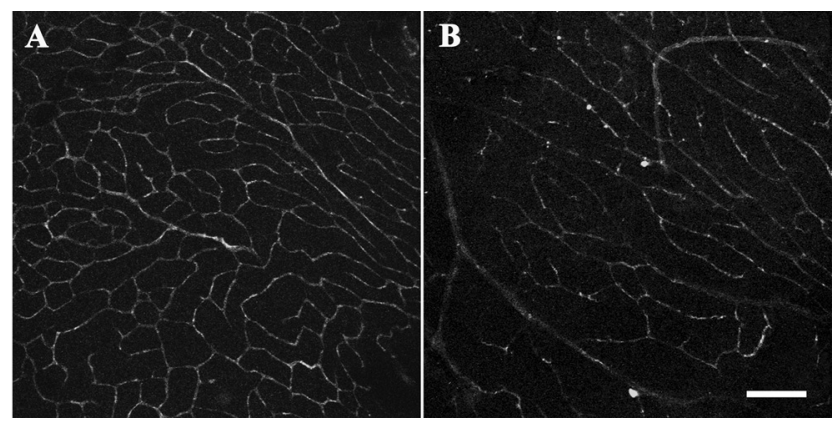

FIGURE 3. Immunohistochemical studies of the $\beta 3-\mathrm{AR}$ distribution pattern in the outer (A) and the inner (B) capillary plexus of the mouse retina. These images are representative of the results obtained in three whole mounts incubated with the goat polyclonal anti- $\beta 3$-ARs. Scale bar, $100 \mu \mathrm{m}$. were drastically reduced by propranolol in the hypoxic mice. We quantitatively determined the antiangiogenic effect of propranolol on retinal neovascularization, and we found that pups treated with propranolol showed significant improvement in the retinopathy score when compared to the oxygen- and the oxygen + vehicle-treated animals $(P<0.05$; Table 3$)$, whereas vehicle injections did not affect the retinopathy score. No significant differences were found between the oxygen- and the oxygen+vehicle-treated mice when compared to the propranolol-treated mice with respect to the different subscores, except for blood vessels tufts and retinal hemorrhages. In particular, propranolol treatment caused a significant decrease in blood vessel tufts and retinal hemorrhages with respect to untreated or vehicle-treated animals $(P<0.01$ and $P<0.001$, respectively; Table 3).

\section{Blood-Retinal Barrier}

To assess the effects of propranolol on $\mathrm{BRB}$, we first examined the expression of the tight junction protein occludin in the retina of the hypoxic mice (Fig. 13A). The results show that the retinal level of occludin decreased in the hypoxic mice to $\sim 35 \%$ of that in control littermates $(P<0.001)$. Vehicle administration did not alter hypoxic levels of occludin, whereas treatment with propranolol at $20 \mathrm{mg} \mathrm{kg}^{-1}$ partially restored the expression of occludin, increasing its level to $\sim 77 \%$ of that in control littermates $(P<0.001)$. The occludin level after propranolol was lower than in the respective normoxia $(\sim 23 \%, P<0.001)$. To further determine the protective effects of propranolol on BRB, we evaluated BRB integrity by determination of vascular leakage of albumin into the retina. The results show that the albumin content was 1.8 -fold higher in the retinas of the hypoxic mice than in the control littermates $(P<0.001)$. Hypoxic levels of albumin were not modified by vehicle administration, whereas administration
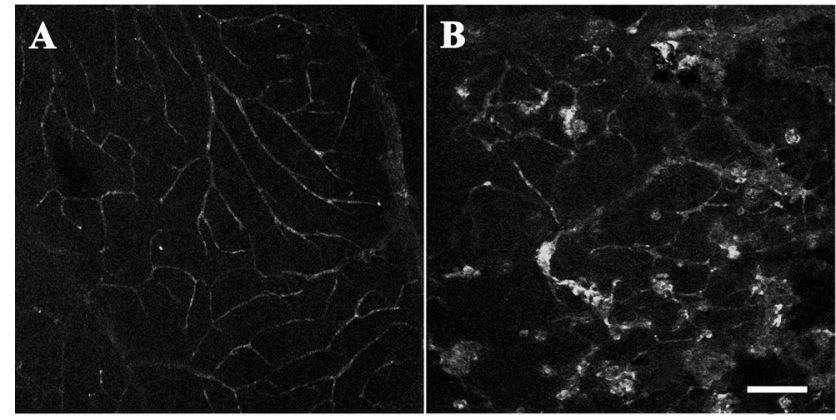

FIGURE 4. Retinal whole mounts showing capillary profiles immunoreactive for $\beta 3$-ARs in control (A) and hypoxic (B) conditions. Hypoxic retinas were characterized by dense $\beta 3$-AR-immunoreactivity that was localized to engorged retinal tufts in the inner capillary plexus. These images are representative of the results obtained in three whole mounts incubated with the goat polyclonal anti- $\beta 3$-ARs. Scale bar, $100 \mu \mathrm{m}$. 
$\mathbf{A}$

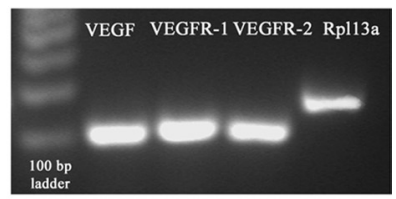

B
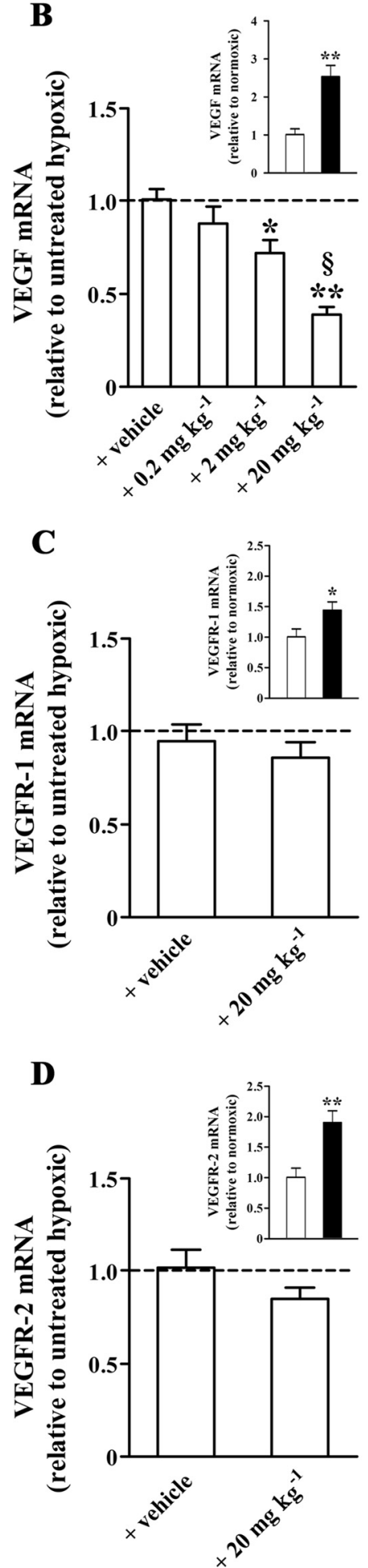

FIGURE 5. Levels of VEGF, VEGFR-1 and VEGFR-2 mRNAs in mouse retinas. (A) The predicted length of each QPCR product was confirmed by agarose gel electrophoresis performed on mRNA extracted from

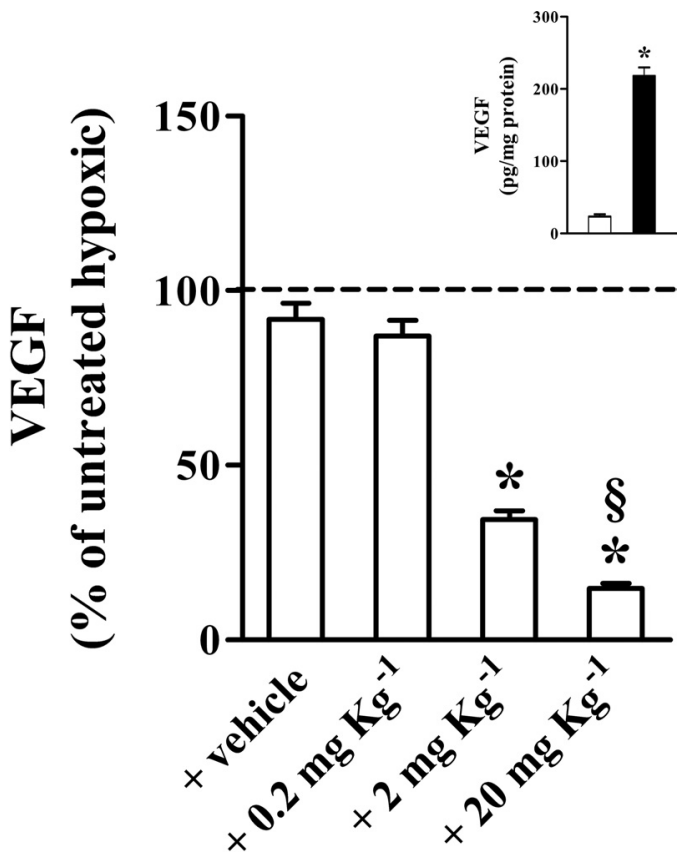

FigURE 6. ELISA quantitation of VEGF protein levels in mouse retinas. Vehicle did not affect the VEGF levels, whereas a dose-dependent decrease of VEGF was observed after treatment with increasing concentrations of propranolol with no effects at $0.2 \mathrm{mg} \mathrm{kg}^{-1}$, a decrease at $2 \mathrm{mg} \mathrm{kg}{ }^{-1}\left({ }^{*} P<0.001\right.$ vs. vehicle-treated mice; ANOVA), and reaching a maximum at $20 \mathrm{mg} \mathrm{kg}^{-1}\left({ }^{*} P<0.001\right.$ vs. vehicle-treated mice and ${ }^{\S} P<0.001$ vs. $2 \mathrm{mg} \mathrm{kg}^{-1}$ propranolol-treated mice; ANOVA). Inset: VEGF levels in normoxic $(\square)$ and hypoxic ( $\square$ ) conditions. Each histogram represents the mean $\pm \mathrm{SE}$ of data from five samples. Each sample was the protein extracted from two retinas.

of propranolol at $20 \mathrm{mg} \mathrm{kg} \mathrm{kg}^{-1}$ significantly decreased extravascular leakage of albumin in the hypoxic mice $(\sim 30 \%$, $P<0.001$; Fig. 13B). The albumin level after propranolol was higher than the respective normoxic level $(\sim 25 \%, P<$ 0.01 ). To confirm the effect of propranolol on the BRB, the vascular permeability of the retinal tissue was assessed qualitatively by Evans blue, in agreement with findings in another study. ${ }^{11}$ The BRB was intact in the normoxic mice. Thus, intravascular injection of Evans blue resulted in a sharp outline of the retinal vessels, with the dye retained within the vessel lumen and no detectable leakage into the tissue parenchyma (Fig. 14A). In hypoxic retinas, there was evidence of breakdown of the BRB with leakage of the dye into the retinal parenchyma (Fig. 14B). Administration of vehicle to the hypoxic mice produced no detectable change in BRB leakage (Fig. 14C), whereas treatment with propranolol at $20 \mathrm{mg} \mathrm{kg}^{-1}$ gave an evident reduction of BRB breakdown (Fig. 14D).

normoxic retinas $(105,116,114$, and $182 \mathrm{bp}$ corresponding to the mRNA of VEGF, VEGFR-1, VEGFR-2, and Rpl13a). (B) Propranolol dose dependently decreased VEGF mRNA in hypoxic retinas $\left({ }^{*} P<0.05\right.$ and ${ }^{* *} P<0.001$ vs. vehicle-treated mice; ${ }^{\circledR} P<0.01$ vs. $2 \mathrm{mg} \mathrm{kg}^{-1}$ propranolol-treated mice; ANOVA). Inset: VEGF mRNA levels in normoxic

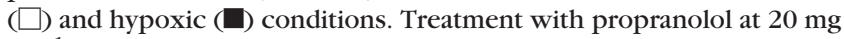
$\mathrm{kg}^{-1}$ did not affect VEGFR-1 (C) and VEGFR-2 (D) mRNAs. Insets: VEGFR-1 and VEGFR-2 mRNAs in normoxic ( $\square$ ) and hypoxic (ם) conditions. Data were analyzed by the $C_{t}$ method with Rpl13a used as the internal standard. Each histogram represents the mean \pm SE of data from four samples. Each sample was the mRNA extracted from two retinas. 
A

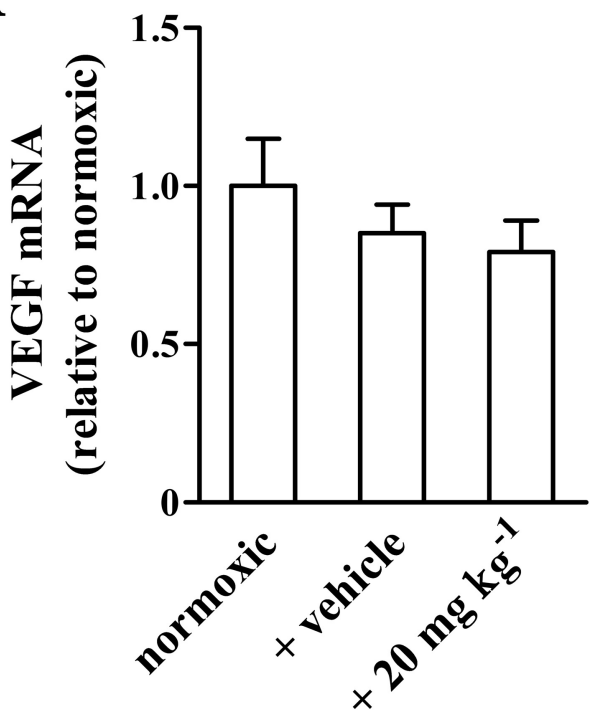

B

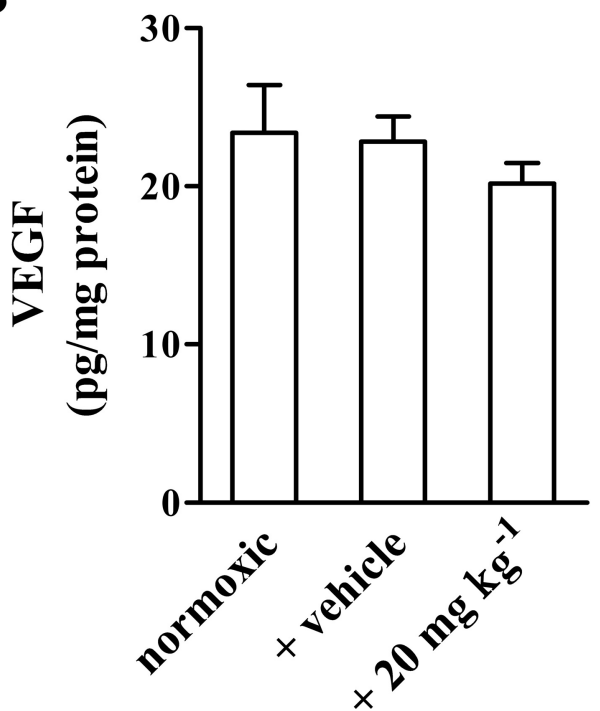

FigURE 7. Levels of VEGF mRNA and protein in the normoxic retina after propranolol. Neither VEGF mRNA (A) nor VEGF content (B) in the normoxic retina was influenced by propranolol at $20 \mathrm{mg} \mathrm{kg}^{-1}$. In QPCR experiments, data were analyzed by the $C_{t}$ method, with Rpl13a as the internal standard. Each histogram represents the mean \pm SE of data from four samples, and each sample was the mRNA extracted from two retinas. In the ELISA experiments, each histogram represents the mean $\pm \mathrm{SE}$ of data from five samples, and each sample was the protein extracted from two retinas.

To investigate whether propranolol could play a role in VEGF-induced BRB breakdown, we treated the control mice with s.c. propranolol from PD12 to -16 and with an intravitreal injection of VEGF at PD13. Maximum vascular leakage was measured at 48 hours after intravitreal injection with a dose of 100 ng VEGF, in agreement with previous studies. ${ }^{12,13}$ Vehicle administration produced no detectable BRB leakage, as evaluated at PD17 (Fig. 15A), whereas VEGF-treated retinas displayed evident BRB breakdown (Fig. 15B). When the mice treated with propranolol at $20 \mathrm{mg} \mathrm{kg}^{-1}$ were injected with VEGF, we found that propranolol did not reduce the vascular hyperpermeability induced by an intravitreal injection of exogenous VEGF (Fig. 15C).

\section{Discussion}

In this study, we report a novel role for the $\beta$-AR blocker propranolol in regulation of retinal angiogenesis and vascular permeability. Systemic administration of propranolol reduced retinal VEGF and IGF-1 expression, retinal neovascularization, and vascular leakage in a mouse model of OIR. In addition, propranolol did not influence retinal VEGF in the normoxic condition nor did it affect VEGF expression in other tissues. These findings imply an antiangiogenic and antipermeability effect of $\beta$-AR blockade that probably acts through downregulation of VEGF and IGF-1 expression, presumably in a parallel manner. Propranolol's effect on VEGF expression is likely to be mediated by HIF- $1 \alpha$. That hypoxia upregulates the $\beta 3$-ARs that appear to be localized to the growing endothelium suggests the possibility that $\beta 3$-ARs mediate the antiangiogenic effects of propranolol in the retina of the OIR mice.

\section{Effects of $\boldsymbol{\beta}$-AR Blockade on Proangiogenic Factors}

In our work, propranolol concentrations affecting both the levels of proangiogenic factors and the gravity of retinal neovascularization were in line with those used previously, although studies of the in vivo use of propranolol to treat retinal neovascularization are scarce. Generally, in rodent studies using propranolol, treatment modalities included oral administration in drinking water (in doses ranging from 5 to $100 \mathrm{mg} \mathrm{kg}^{-1}$ $\left.\mathrm{day}^{-1}\right){ }^{26,48}$ as well as s.c. administration or i.p. injection (in
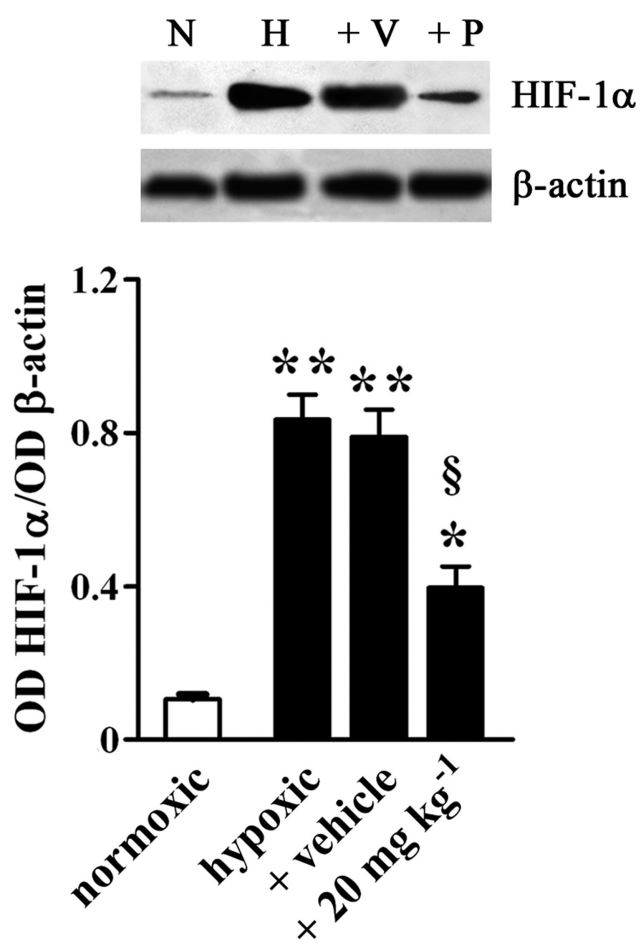

Figure 8. Levels of HIF-1 $\alpha$ in normoxic $(\square)$ and hypoxic $(\square)$ conditions, as evaluated by Western blot with $\beta$-actin used as the loading control. Densitometric analysis showed that HIF- $1 \alpha$ was increased by hypoxia $\left({ }^{* *} P<0.001\right.$ vs. normoxic; ANOVA). The hypoxic level of HIF- $1 \alpha$ was unaffected by vehicle treatment, whereas it was decreased by propranolol at $20 \mathrm{mg} \mathrm{kg}^{-1}\left({ }^{\S} P<0.01\right.$ vs. vehicle-treated mice; ANOVA). HIF-1 $\alpha$ level after propranolol was higher than the respective normoxic level $\left({ }^{*} P<0.01\right.$; ANOVA). Each histogram represents the mean \pm SE of data from three samples. Each sample was the protein extracted from four retinas. N, normoxia; H, hypoxia; V, vehicle; $\mathrm{P}$, propranolol. 
A

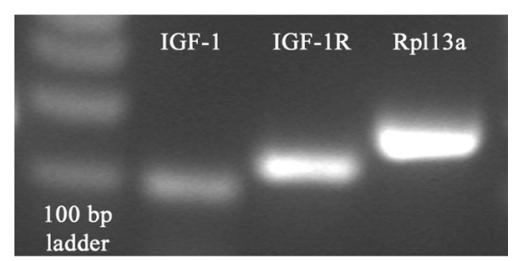

B

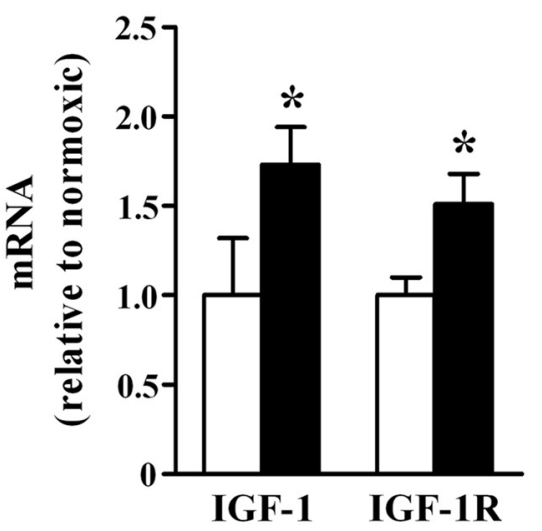

$\mathrm{C}$

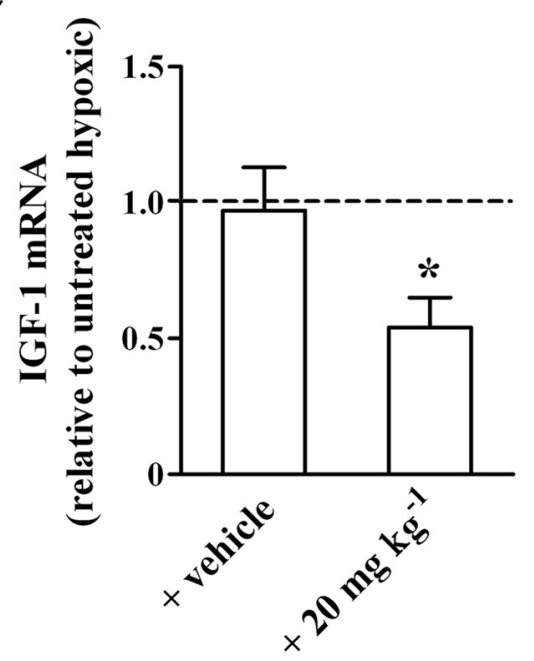

D

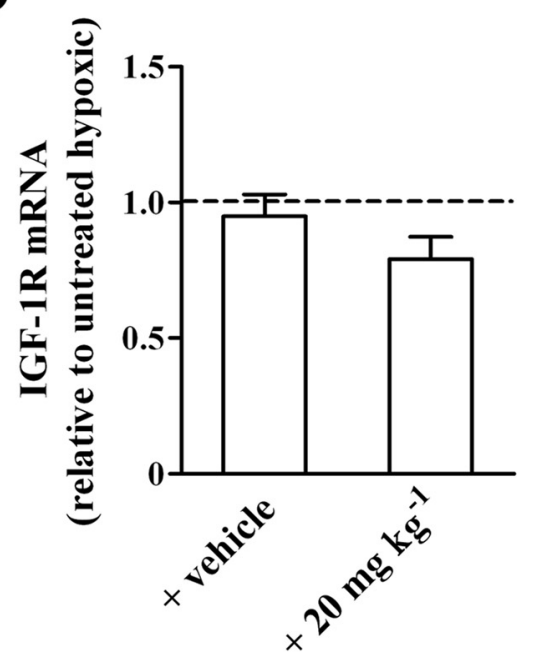

doses ranging from 1 to $30 \mathrm{mg} \mathrm{kg}{ }^{-1}$ ). ${ }^{49,50}$ The propranolol dose used the most in infants to treat hemangiomas is $2 \mathrm{mg}$ $\mathrm{kg}^{-1}$ day $^{-1}$ administered orally two or three times a day, depending on the severity of the hemangiomas. ${ }^{51,52}$ As shown by our results, s.c. or i.p. propranolol produces comparable effects on VEGF levels indicating that both modalities of administration may provide the retina with similar drug concentrations, although it is difficult to conjecture about the drug concentration that actually reaches the retina.

Both experimental and clinical studies have reported an important role of VEGF in pathologic retinal angiogenesis. ${ }^{4,53}$ Of the VEGF receptors, VEGFR-2 is considered to be the receptor that mediates functional VEGF signaling in endothelial cells, whereas the function of VEGFR-1 remains to be fully disclosed. ${ }^{54}$ Our finding that hypoxia increases the levels of VEGF and its receptors is consistent with previous findings. ${ }^{33,44}$ Our additional result that propranolol drastically inhibited hypoxia-induced VEGF production provides the first demonstration that $\beta$-ARs are coupled to a modulation of VEGF in the OIR model. The present results are in line with those in another study demonstrating that timolol reduces the severity of OIR in the newborn rat, possibly through VEGF downregulation. ${ }^{27}$ On the other hand, there are also findings demonstrating that propranolol does not affect retinal VEGF in rats with DR. ${ }^{26}$ Either the different administration route or different dosage can be assumed to be the possible cause of this discrepancy. However, the possibility that $\beta$-AR's control of angiogenesis can be regulated by diverse mechanisms in OIR and DR should be also considered. In this respect, topical administration of isoproterenol has recently been demonstrated to prevent ERG alterations and to inhibit metabolic abnormalities found in DR rats. ${ }^{24}$ In addition, propranolol has been shown to produce a dysfunctional ERG and increase angiogenic growth factors in nondiabetic rodents. ${ }^{25}$ In our study, propranolol did not affect the VEGF level in the normoxic retina, but it reduced VEGF overproduction in the hypoxic retina, suggesting differential regulation of VEGF transcription in normoxic and hypoxic conditions. This possibility is supported by the additional finding that $\beta$-AR blockade did not influence VEGF levels in brain, lung, or heart, in which VEGF expression is not regulated by hypoxia, indicating that these organs probably do not experience hypoxia in the OIR model. In response to systemic hypoxia, organ-specific regulation of the HIF system, which primarily regulates VEGF expression in hypoxic conditions, has been described in rodents with HIF-1 $\alpha$ accumulation observed only in conditions of severe hypoxia (for references, see Ref. 55). The OIR model is of relative hypoxia in which the exposure to hyperoxia before the retinal vascularization is completed leads to the arrest or retardation of normal retinal vascular development. When the animals are returned to the normoxic environment, they are in a relative hypoxic situation in which the retina lacks the normal vasculature that is necessary to support the neural tissue in normoxic conditions. The

FIGURE 9. Levels of IGF-1 and $-1 \mathrm{R}$ mRNAs in mouse retinas. (A) The predicted length of each QPCR product was confirmed by agarose gel electrophoresis performed on mRNA extracted from normoxic retinas (94, 127, and 182 bp corresponding to the mRNA of IGF-1, IGF-1R, and Rpl13a). (B) QPCR evaluation of IGF-1 and IGF-1R mRNAs in normoxic $(\square)$ and hypoxic $(\square)$ conditions. Normoxic IGF-1 and IGF-1R mRNAs were increased by hypoxia $\left({ }^{*} P<0.05\right.$ vs. the respective normoxic; unpaired $t$-test). (C, D) IGF-1 and IGF-1R mRNAs in hypoxic retinas after treatment with either vehicle or propranolol at $20 \mathrm{mg} \mathrm{kg}$. Propranolol significantly decreased IGF- 1 mRNA $\left({ }^{*} P<0.05\right.$ vs. vehicletreated mice; ANOVA), whereas it did not affect IGF-1R mRNA. Data were analyzed by the $\mathrm{C}_{\mathrm{t}}$ method using Rpl13a as the internal standard. Each histogram represents the mean \pm SE of data from four samples. Each sample was the mRNA extracted from two retinas. 


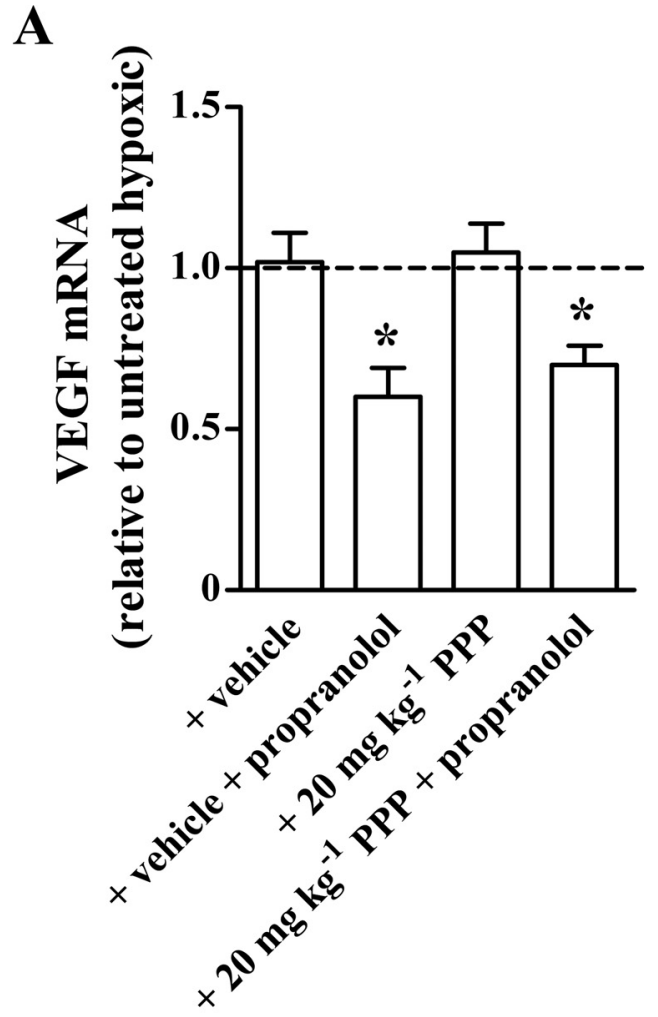

B

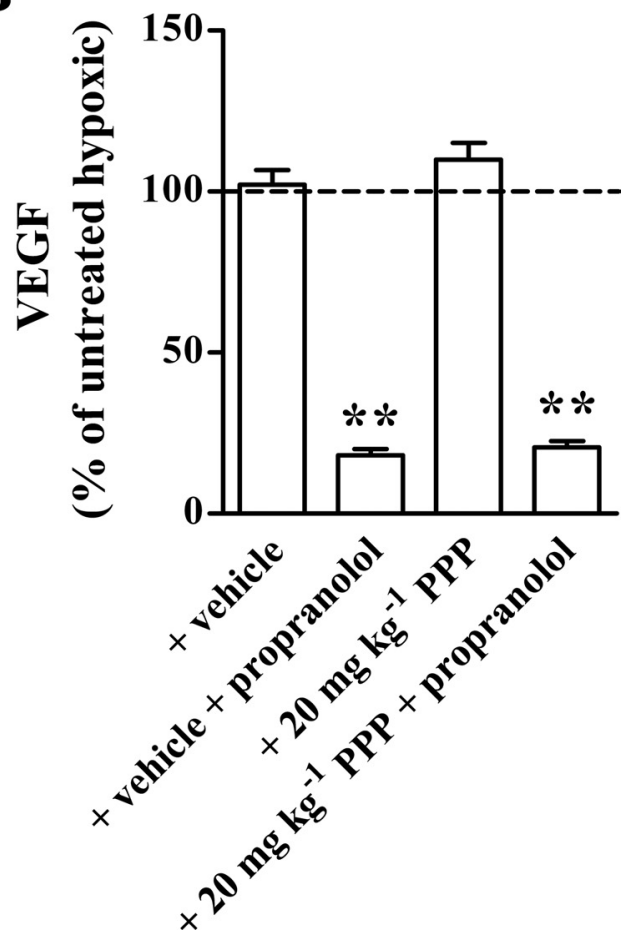

FIGURE 10. VEGF expression in OIR mice treated with picropodophyllin (PPP), an inhibitor of IGF-1R phosphorylation. (A) QPCR evaluation of VEGF mRNA and (B) ELISA quantitation of VEGF content in the hypoxic retina after treatment with vehicle or PPP $\left(20 \mathrm{mg} \mathrm{kg}^{-1}\right)$ either alone or in combination with propranolol at $20 \mathrm{mg} \mathrm{kg}$. Vehicle or PPP did not influence hypoxic levels of VEGF mRNA and protein. VEGF mRNA and protein levels after $\mathrm{PPP}+$ propranolol were not significantly different from those measured after vehicle+ propranolol. In QPCR experiments, data were analyzed by the $\mathrm{C}_{\mathrm{t}}$ method with Rpl13a used as the internal standard. Each histogram retina is one of the body's most metabolically demanding tissues, and this ischemic situation results in unregulated, VEGF overproduction that leads to retinal neovascularization.

As was also shown by the present results, the hypoxiainduced increase in retinal levels of IGF-1 and -1R was in line with previous results demonstrating that the IGF system is involved in retinal angiogenesis. ${ }^{56,57}$ For instance, serum IGF-1 levels correlate positively with the degree of ROP and insufficient IGF-1 has been suggested to be a factor involved in ROP development. ${ }^{1}$ Our finding that propranolol reduces the hypoxia-induced increase in IGF-1 is the first demonstration that $\beta$-ARs may control retinal angiogenesis through IGF-1. Little is known about possible cross talk between $\beta$-ARs and IGF-1. For instance, in the rat, $\beta$-AR stimulation has been shown to induce cardiac hypertrophy through the IGF-1 axis. ${ }^{58}$ In addition, IGF-1 treatment influences astrocyte function through a $\beta 2$-AR-dependent mechanism. ${ }^{59}$ Our finding that propranolol does not influence IGF-1R either in normoxic or in hypoxic conditions is in line with previous results in rat retina. ${ }^{25}$

In the present study, the IGF-1R antagonist PPP did not affect hypoxic levels of retinal VEGF, indicating that VEGF expression in the OIR model was not substantially controlled by interactions between IGF-1 and IGF-1R. This finding is in line with the result that, in OIR mice, treatment with the long-acting IGF-1R antagonist JB3 suppresses retinal neovascularization without affecting VEGF levels. ${ }^{60}$ On the other hand, PPP administration has recently been shown to reduce VEGF expression in a murine model of choroidal neovascularization. ${ }^{6}$ The additional result that PPP administration to propranololtreated mice does not affect the propranolol-induced inhibition of retinal VEGF suggests that propranolol's effects on VEGF do not involve IGF-1 signaling, although IGF-1 is a potent inducer of VEGF. ${ }^{6,7}$ By inhibiting IGF-1 and VEGF levels, propranolol inhibits the neovascularization process directly through decreasing the endogenous angiogenic effect of VEGF and indirectly via attenuation of IGF-1 signaling, which has a permissive role in VEGF-induced neovascularization.

\section{Effects of Propranolol on Retinal Neovascularization}

As a result of the inhibitory effects that propranolol exerts on hypoxia-induced upregulation of proangiogenic factors, propranolol ameliorates retinal angiogenesis in response to hypoxic insult, indicating that $\beta$-ARs may regulate neovascularization in the OIR model. In line with the present results, a role for $\beta 3$-ARs in the control of cell proliferation and migration has been determined in human retinal endothelial cells. ${ }^{22}$ In human choroidal endothelial cells, $\beta 3$-ARs may play a role in cell invasion and elongation, while playing a more limited function in regulation of cell proliferation. ${ }^{39}$ In addition, a role for $\beta$-ARs in vascular remodelling of the rat choroid has been demonstrated. ${ }^{61}$ Moreover, in a rat model of chronic hind limb ischemia, $\beta 2$-AR overexpression results in ameliorated angiogenic response to ischemia, whereas $\beta 2$-AR blockade prevents the proliferative response to isoproterenol in bovine aortic endothelial cells. ${ }^{62}$ Finally, propranolol has been shown to inhibit tubulogenesis and matrix metalloproteinase-9 secretion in human brain microvascular endothelial cells. ${ }^{63}$

represents the mean \pm SE of data from four samples. Each sample was the mRNA extracted from two retinas. In ELISA experiments, each histogram represents the mean \pm SE of data from five samples, and each sample was the protein extracted from two retinas. 
A

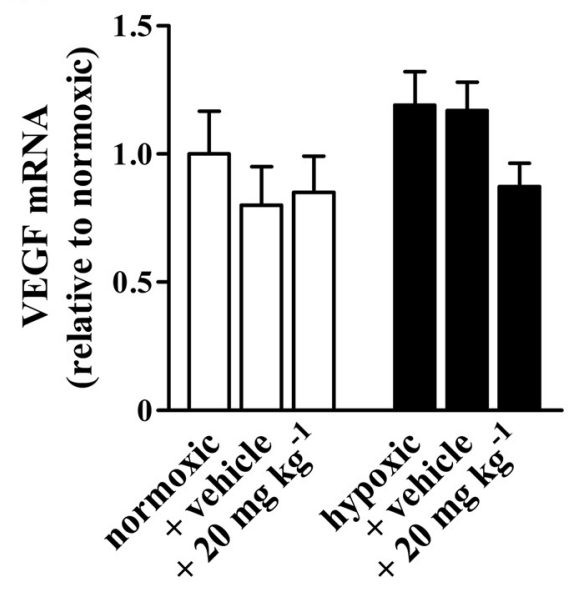

C

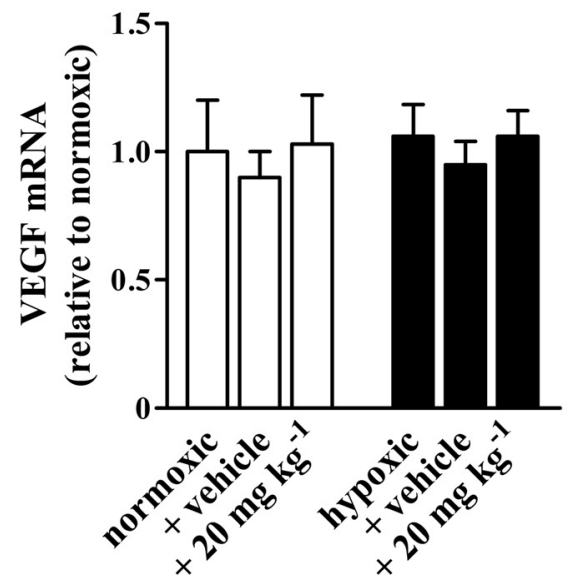

E

FIGURE 11. QPCR evaluation of VEGF MRNA (A, C, E) and ELISA quantitation of VEGF content $(\mathbf{B}, \mathbf{D}$, F) in mouse brain (A, B), lungs (C, D), and heart (E, F) in normoxic ( $\square$ ) and hypoxic ( $)$ conditions. Hypoxia did not affect VEGF levels in brain, lungs, or heart. Neither normoxic nor hypoxic VEGF levels were influenced by either vehicle or propranolol at $20 \mathrm{mg} \mathrm{kg}^{-1}$. In QPCR experiments, each histogram represents the mean $\pm \mathrm{SE}$ of data from four samples. Each sample was the mRNA extracted from two retinas. In ELISA experiments, each histogram represents the mean $\pm S E$ of data from five samples. Each sample was the protein extracted from two retinas.

\section{Effects of Propranolol on BRB}

$\mathrm{BRB}$ resides in the tight junctions between RPE cells (outer BRB) and between endothelial cells in the retinal vasculature (inner BRB). It is known that retinal endothelial cells are susceptible to hypoxia with resulting increased permeability and BRB dysfunction. ${ }^{8}$ Consistent with previous studies, in our experiments hypoxia downregulated the tight junction protein occludin, increased the retinal content of albumin, and caused
B

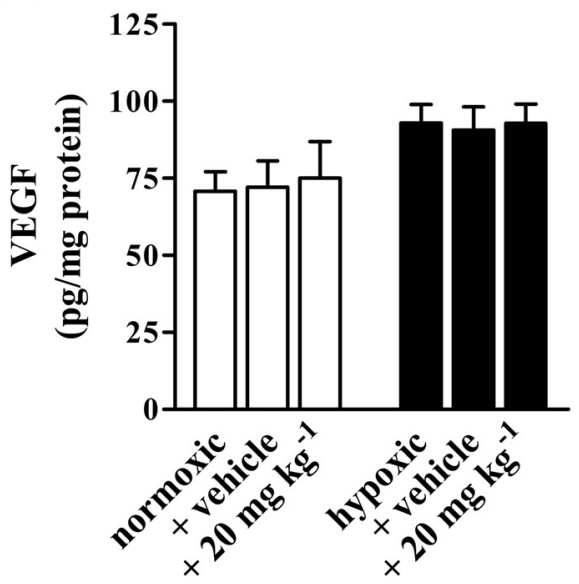

D

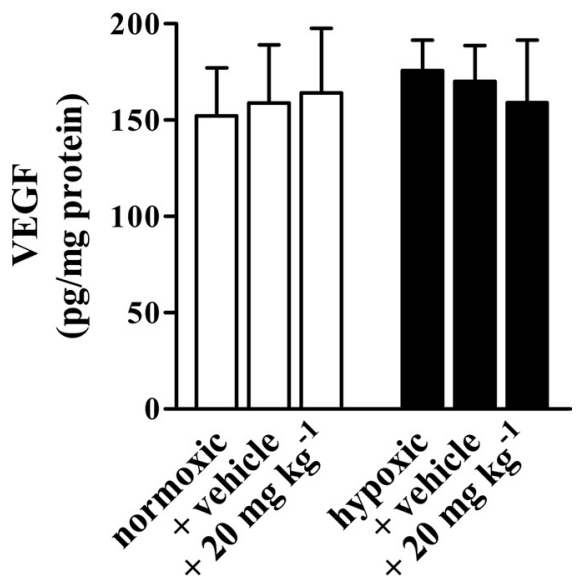

F

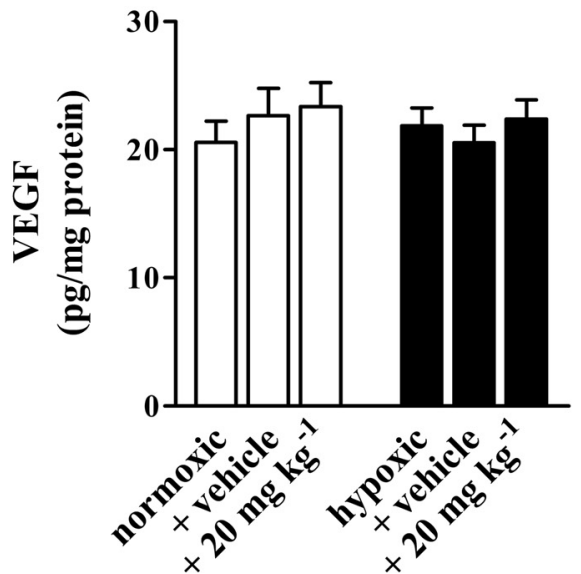



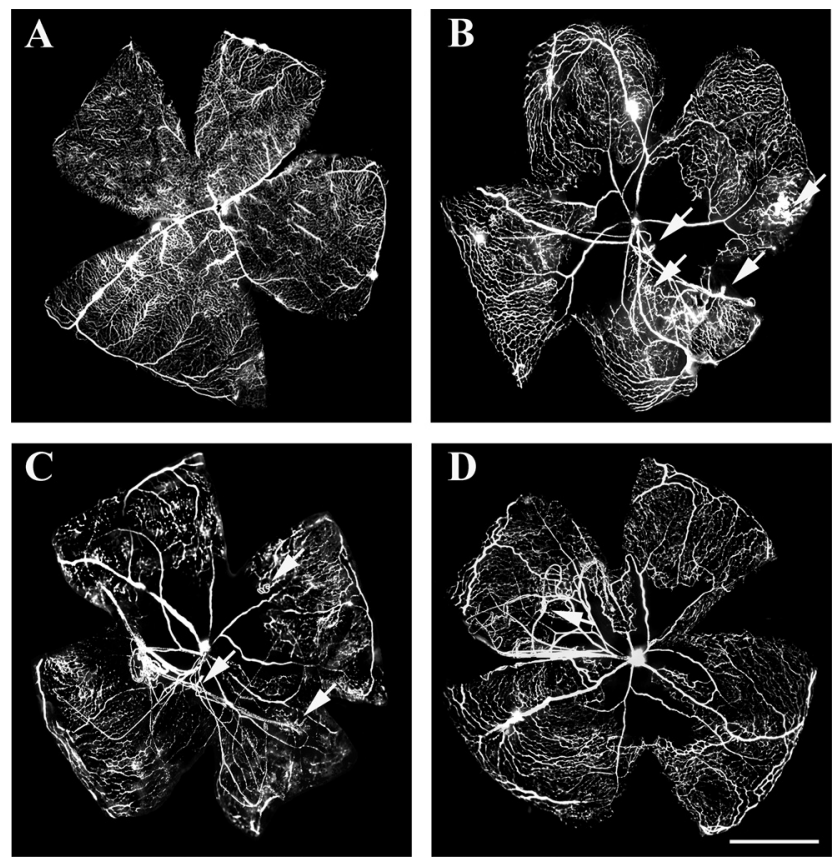

FIGURE 12. Flat-mounted retinas perfused with fluorescein-dextran of PD17 mice exposed to room air (A) or to $75 \% \pm 2 \%$ oxygen from PD 7 to -12 (B-D), untreated (B) or treated with vehicle (C) or propranolol (D) at $20 \mathrm{mg} \mathrm{kg}$-1 from PD12 to -16 . Hyperoxia followed by normoxia for 5 days produced the central loss of blood vessels and the formation of vessel tufts (arrows). Propranolol treatment improved the blood vessel tufts, whereas vehicle administration had no effect. Scale bar, $1 \mathrm{~mm}$.

junction proteins and results in BRB breakdown, has been well established. ${ }^{8}$ Thus, the blockade of VEGF expression in hypoxic retina may be responsible, at least in part, for the propranolol-induced reduction of vascular leakage in OIR mice. More evidence to support the reduction in vascular leakage via blockade of VEGF production is that propranolol did not reduce the vascular hyperpermeability induced by intravitreal injection of exogenous VEGF. This finding suggests that propranolol does not influence the VEGF-induced downstream signaling pathways, consistent with the result that the expression of VEGF receptors is not changed after propranolol treatment. In contrast, corticosteroids have been shown to inhibit VEGF-induced vascular leakage in a rabbit BRB model, indicating that they modulate signaling or effector proteins downstream of the VEGF receptor. ${ }^{12}$

\section{Mechanisms of Action of Propranolol on Angiogenesis}

$\beta$-AR messengers and proteins are expressed at the retinal level as, for instance, $\beta 1$ - and $\beta 2$-ARs in the rat retina ${ }^{15}$ and $\beta 1$-ARs in the avian retina. ${ }^{16} \beta 1$ - and $\beta 2$-ARs are present in Müller cells of the rat, in which they influence cytokine production in response to hyperglycemia. ${ }^{17}$ In the human retinal pigment epithelium, $\beta$-ARs appear to regulate the production of the antiangiogenic pigment epithelial-derived factor. ${ }^{65} \beta 1$ - and $\beta 3$ ARs, but not $\beta 2$-ARs, are expressed in human retinal and choroidal endothelial cells in which a role of $\beta 3$-ARs in angiogenic processes has been demonstrated. ${ }^{22,39}$ In addition, there is pharmacologic evidence that $\beta 2$ - and $\beta 3$-ARs are expressed in the retinal blood vessels of the rat. ${ }^{66}$

There are studies demonstrating that hypoxia differentially affects $\beta$-ARs in different organs but not in the retina. In rat heart, for instance, prolonged exposure to hypoxia decreases $\beta$-AR density and signaling. ${ }^{67}$ In addition, in vitro hypoxia impairs $\beta 2$-AR signaling in rat alveolar epithelial cells, ${ }^{68}$ whereas prolonged prenatal hypoxia does not influence $\beta$-AR density, but decreases postnatal $\beta$-AR sensitivity in chicken embryonic heart. ${ }^{14}$ Thus, changes in $\beta$-ARs seem to depend on the tissue as well as the degree and duration of hypoxia. To the best of our knowledge, this is the first demonstration that hypoxia upregulates $\beta 3$-AR expression in the retina of OIR mice and that $\beta 3$-AR upregulation is associated with the onset of angiogenesis. $\beta 3$-AR overexpression is not accompanied by changes in $\beta 3$-AR gene expression, indicating the involvement of translational or posttranslational mechanisms. As shown by our immunohistochemical studies, dense $\beta 3$-AR-IR is localized to engorged retinal tufts in the inner capillary network that lies in the ganglion cell layer and is known to undergo to the most dramatic alterations as a consequence of hypoxia. ${ }^{69}$

Little information is available on which distinct $\beta$-AR may mediate angiogenesis control by the adrenergic system in the retina. For instance, the $\beta 1$-AR antagonist atenolol does not seem to influence either retinal vascular disease or retinal dysfunction in diabetic rats. ${ }^{70,71}$ The finding that in the retina of OIR mice, $\beta 3$-ARs are localized to the growing endothelium suggests the possibility that $\beta 3$-ARs mediate the antiangiogenic effects of propranolol, in line with previous findings demonstrating an important role of $\beta 3$-ARs in regulating proliferation and migration of retinal endothelial cells. ${ }^{22}$

Much work has been done to clarify the functional role of transcription factors regulating target genes involved in angiogenesis and HIF-1 appears of particular interest because its activation is coupled to regulation of VEGF. ${ }^{3}$ In line with previous studies, ${ }^{2}$ HIF- $1 \alpha$ is upregulated by hypoxia in the

TABLE 3. Retinopathy Subscore and Total Score

\begin{tabular}{|c|c|c|c|}
\hline & Hypoxia & +Vehicle & +Propranolol $20 \mathrm{mg} \mathrm{kg}^{-1}$ \\
\hline Number of animals & 6 & 6 & 13 \\
\hline Blood vessel tufts & $2(1.5,2)$ & $2(1.5,2)$ & $1(1,2)^{*}$ \\
\hline Central avascular area & $3(2,3)$ & $2.5(2,3)$ & $3(2,3)$ \\
\hline $\begin{array}{l}\text { Presumed extraretinal } \\
\text { neovascularization }\end{array}$ & $2(1,2)$ & $2(1,2)$ & $2(1,2)$ \\
\hline Retinal hemorrhage & $1(1,1)$ & $1(1,1)$ & $0(0,0.5) \dagger$ \\
\hline Blood vessel tortuosity & $2(2,3)$ & $2.5(2,3)$ & $2(2,3)$ \\
\hline $\begin{array}{l}\text { Total retinopathy } \\
\text { score }\end{array}$ & $9.5(8,10)$ & $9(8.5,11)$ & $8(7,9) \ddagger$ \\
\hline
\end{tabular}

Data are expressed as the median (25th, 75 th quartiles).

* $P<0.01$ vs. vehicle-treated.

$\dagger P<0.001$ vs. vehicle-treated.

$\ddagger P<0.05$ vs. vehicle-treated. 
A
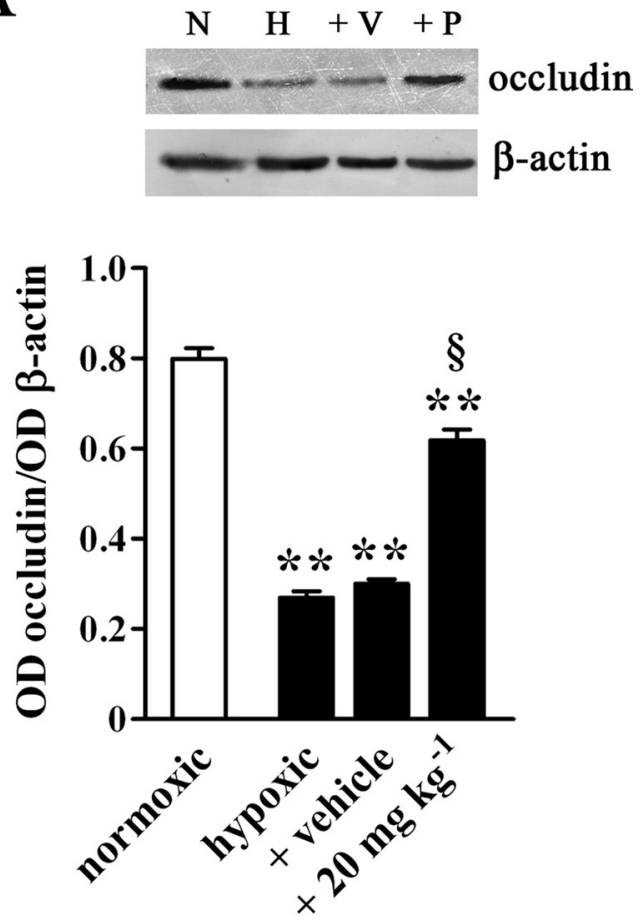

B
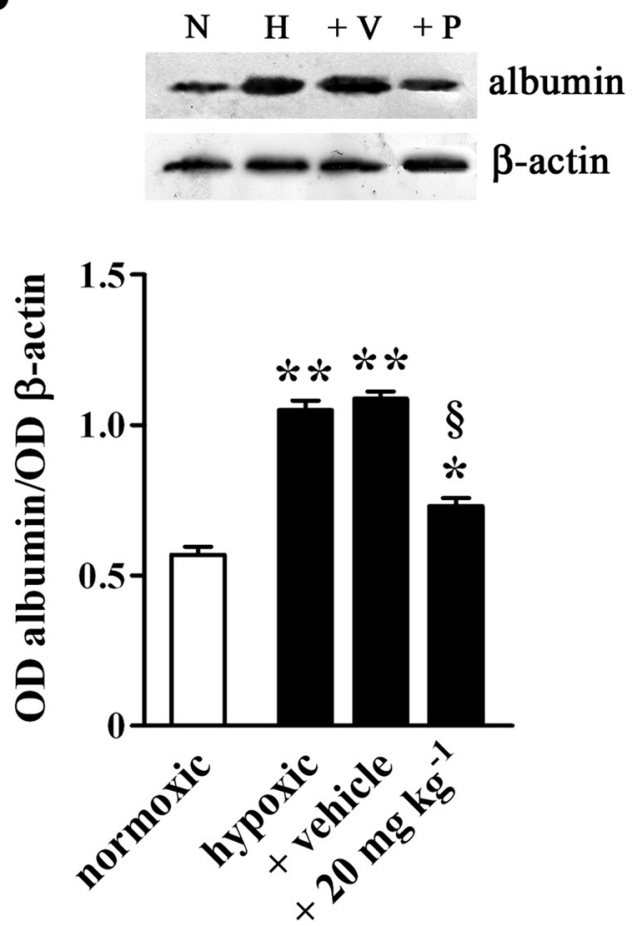

Figure 13. Levels of occludin (A) and albumin (B) in normoxic ( $\square$ ) and hypoxic $(\square)$ conditions, as evaluated by Western blot with $\beta$-actin as the loading control. Densitometric analysis showed that occludin was decreased by hypoxia (** $P<0.001$ vs. normoxic; ANOVA), whereas albumin was increased $(* * P<0.001$ vs. normoxia; ANOVA). Hypoxic levels of both occludin and albumin were unaffected by vehicle treatment. (A) Propranolol at $20 \mathrm{mg} \mathrm{kg}^{-1}$ increased occludin $(\$ P<0.001$ vs. vehicle-treated mice; ANOVA). The occludin level after propranolol was lower than the respective normoxic level ${ }^{* *} P<$
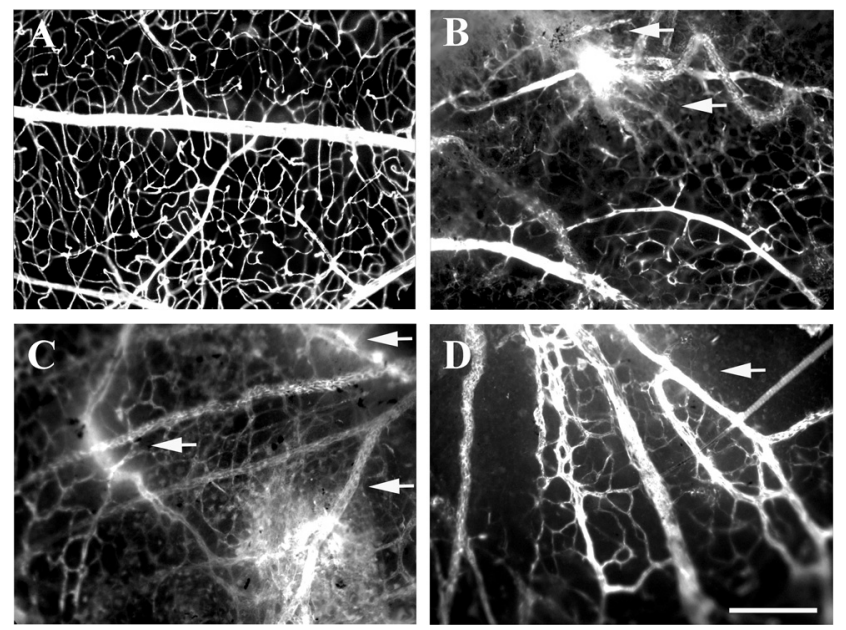

FigURE 14. Effect of propranolol on blood-retinal vascular leakage after hypoxia, as qualitatively evaluated with the Evans blue method. In normoxia (A), retinal vessels were sharply outlined, and there was no Evans blue leakage from the vessels. In hypoxia (B), there was evidence of breakdown of the BRB with leakage of the dye into the retinal parenchyma. Vehicle administration to hypoxic mice $(\mathbf{C})$ produced no detectable change in BRB leakage, whereas treatment with propranolol at $20 \mathrm{mg} \mathrm{kg}^{-1}$ (D) induced an evident decrease in dye leakage. Arrows: vascular leakage. Six mice were used for each experimental condition. Scale bar, $200 \mu \mathrm{m}$.

retina of OIR mice, suggesting that HIF- $1 \alpha$ may help to mediate proliferation of blood vessels in the neovascular retina. In the present study, upregulation of HIF- $1 \alpha$ in the hypoxic retina consistently reduced by propranolol, indicating that HIF- $1 \alpha$ is likely to participate in the mechanisms coupling $\beta$-AR blockade to VEGF inhibition. In this respect, it has been observed that carvedilol, a nonselective $\beta$-AR blocker, reduces the expression of both HIF- $1 \alpha$ and VEGF in a rat model of cardiac hypertrophy. ${ }^{72}$ In addition, in the retina of OIR mice, statins exert beneficial effects in ameliorating vascular dysfunction by preventing hypoxia-induced HIF-1 $\alpha$ upregulation. $^{2}$

\section{Clinical Implications}

Most of recent therapeutic interventions against ROP have focused on the mechanisms and the factors leading to new vessel growth. In this respect, there has been great interest in an anti-VEGF therapy that provides rapid, effective treatment for ROP, although recent reports are cautious on its success. In this respect, our finding that in hypoxic retinas propranolol downregulates proangiogenic factors, ameliorates proangiogenic effect of hypoxia, and repairs, at least in part, BRB breakdown is particularly intriguing in light of a possible therapeutic use of $\beta$-AR blockers to counteract retinal neovascularization in ROP.

\section{Conclusion}

The decrease in retinal production of VEGF and IGF-1 induced by propranolol could represent a potential dose-dependent retinoprotective effect of the drug. Extrapolation of these experimental findings to the human situation of ROP is difficult,

0.001; ANOVA). (B) Propranolol at $20 \mathrm{mg} \mathrm{kg}^{-1}$ decreased albumin ( $(P<0.001$ vs. vehicle-treated mice; ANOVA). The albumin level after propranolol was higher than the respective normoxic level $\left({ }^{*} P<0.01\right.$; ANOVA). Each histogram represents the mean $\pm \mathrm{SE}$ of data from three samples. Each sample was the protein extracted from four retinas. N, normoxia; $\mathrm{H}$, hypoxia, $\mathrm{V}$, vehicle; $\mathrm{P}$, propranolol. 

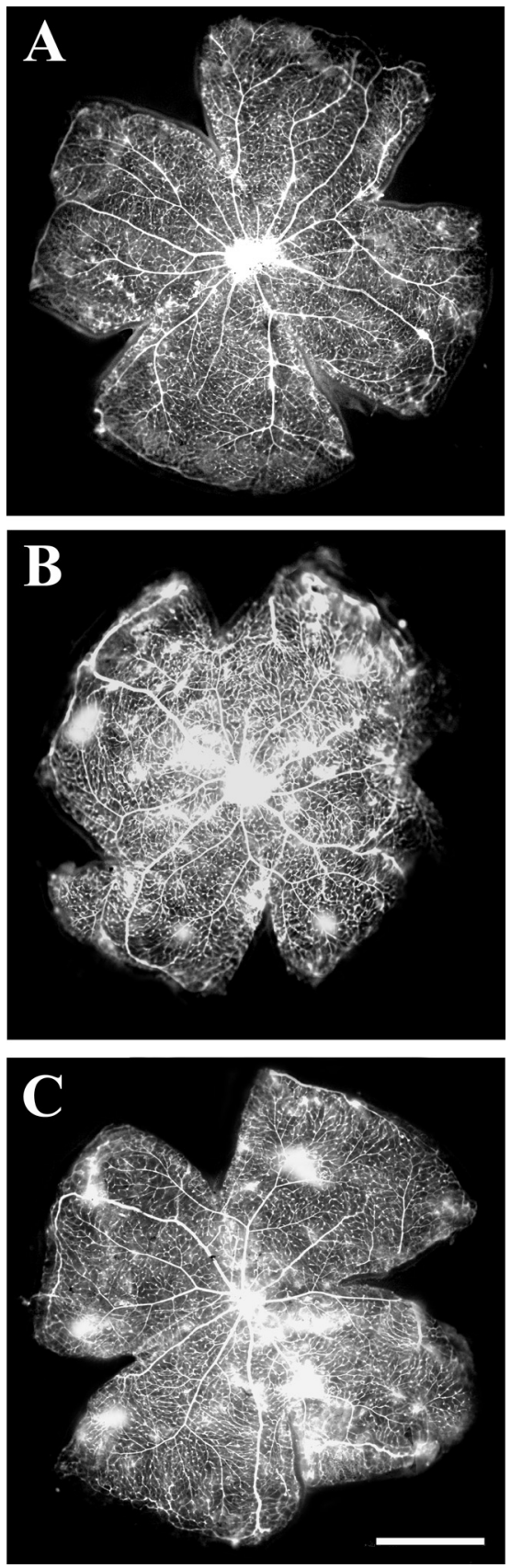

FIGURE 15. Qualitative evaluation of VEGF-induced retinal vascular permeability by Evans blue perfusion. Fluorescence photomicrographs of retinal flat mounts from mice intravitreally injected at PD13 with PBS (A) and $100 \mathrm{ng} \mathrm{VEGF}_{164}$, either alone (B) or in combination with administration of propranolol at $20 \mathrm{mg} \mathrm{kg}^{-1}$ s.c. from PD12 to -16 (C). PBS injection produced no Evans blue leakage from the vessels, whereas BRB breakdown with leakage of the dye was evident after VEGF injection. Treatment with propranolol did not influence dye leakage. Six mice, either untreated or treated with propranolol, were used. Scale bar, $1 \mathrm{~mm}$.

but they may represent another piece in the polymorphic puzzle of this complex disease.

\section{Acknowledgments}

The authors thank William Hodos and Giovanni Casini for critical reading of the manuscript, Angelo Gazzano and Gino Bertolini for assistance with mouse colonies, and Elena Cupisti for technical assistance.

\section{References}

1. Chen J, Smith LE. Retinopathy of prematurity. Angiogenesis. 2007; 10:133-140.

2. Bartoli M, Al-Shabrawey M, Labazi M, et al. HMG-CoA reductase inhibitors (statin) prevents retinal neovascularization in a model of oxygen-induced retinopathy. Invest Ophthalmol Vis Sci. 2009;50: $4934-4940$.

3. Semenza GL. Hydroxylation of HIF-1: oxygen sensing at the molecular level. Physiology (Bethesda). 2004;19:176-182.

4. Penn JS, Madan A, Caldwell RB, Bartoli M, Caldwell RW, Hartnett ME. Vascular endothelial growth factor in eye disease. Prog Retin Eye Res. 2008;27:331-371.

5. Treins C, Giorgetti-Peraldi S, Murdaca J, Monthouël-Kartmann MN, Van Obberghen E. Regulation of hypoxia-inducible factor (HIF)-1 activity and expression of HIF hydroxylases in response to insulinlike growth factor I. Mol Endocrinol. 2005;19:1304-1317.

6. Economou MA, Wu J, Vasilcanu D, et al. Inhibition of VEGF secretion and experimental choroidal neovascularization by picropodophyllin (PPP), an inhibitor of the insulin-like growth factor-1 receptor. Invest Ophthalmol Vis Sci. 2008;49:2620-2626.

7. Poulaki V, Joussen AM, Mitsiades N, Mitsiades CS, Iliaki EF, Adamis AP. Insulin-like growth factor-I plays a pathogenetic role in diabetic retinopathy. Am J Pathol. 2004;165:457-469.

8. Kaur C, Foulds WS, Ling EA. Blood-retinal barrier in hypoxic ischaemic conditions: basic concepts, clinical features and management. Prog Retin Eye Res. 2008;27:622-647.

9. Deissler H, Deissler H, Lang S, Lang GE. VEGF-induced effects on proliferation, migration and tight junctions are restored by ranibizumab (Lucentis) in microvascular retinal endothelial cells. $\mathrm{Br} \mathrm{J}$ Ophthalmol. 2008;92:839-843.

10. Li J, Wang JJ, Chen D, et al. Systemic administration of HMG-CoA reductase inhibitor protects the blood-retinal barrier and ameliorates retinal inflammation in type 2 diabetes. Exp Eye Res. 2009; 89:71-78

11. Leal EC, Manivannan A, Hosoya $\mathrm{K}$, et al. Inducible nitric oxide synthase isoform is a key mediator of leukostasis and blood-retinal barrier breakdown in diabetic retinopathy. Invest Ophthalmol Vis Sci. 2007; 48:5257-5265.

12. Edelman JL, Lutz D, Castro MR. Corticosteroids inhibit VEGFinduced vascular leakage in a rabbit model of blood-retinal and blood-aqueous barrier breakdown. Exp Eye Res. 2005;80:249-258.

13. Ishida S, Usui T, Yamashiro K, et al. VEGF164 is proinflammatory in the diabetic retina. Invest Ophthalmol Vis Sci. 2003;44:21552162.

14. Lindgren I, Altimiras J. Chronic prenatal hypoxia sensitizes betaadrenoceptors in the embryonic heart but causes postnatal desensitization. Am J Physiol Regul Integr Comp Physiol. 2009;297: R258-R264.

15. Smith CP, Sharma S, Steinle JJ. Age-related changes in sympathetic neurotransmission in rat retina and choroid. Exp Eye Res. 2007; 84:75-81.

16. Kubrusly RC, Ventura AL, de Melo Reis RA, et al. Norepinephrine acts as D1-dopaminergic agonist in the embryonic avian retina: late expression of beta1-adrenergic receptor shifts norepinephrine specificity in the adult tissue. Neurochem Int. 2007;50:211-218.

17. Walker RJ, Steinle JJ. Role of beta-adrenergic receptors in inflammatory marker expression in Müller cells. Invest Ophthalmol Vis Sci. 2007; $48: 5276-5281$.

18. Guo K, Ma Q, Wang L, et al. Norepinephrine-induced invasion by pancreatic cancer cells is inhibited by propranolol. Oncol Rep. 2009;22:825-830.

19. Yang EV, Kim SJ, Donovan EL, et al. Norepinephrine upregulates VEGF, IL-8, and IL-6 expression in human melanoma tumor cell lines: implications for stress-related enhancement of tumor progression. Brain Behav Immun. 2009;23:267-275.

20. Seya Y, Fukuda T, Isobe K, Kawakami Y, Takekoshi K. Effect of norepinephrine on RhoA, MAP kinase, proliferation and VEGF expression in human umbilical vein endothelial cells. Eur J Pharmacol. 2006;553:54-60. 
21. Weil J, Benndorf R, Fredersdorf S, Griese DP, Eschenhagen T. Norepinephrine upregulates vascular endothelial growth factor in rat cardiac myocytes by a paracrine mechanism. Angiogenesis. 2003;6:303-309.

22. Steinle JJ, Booz GW, Meininger CJ, Day JN, Granger HJ. Beta 3-adrenergic receptors regulate retinal endothelial cell migration and proliferation. J Biol Chem. 2003;278:20681-20686.

23. Steinle JJ, Cappocia FC Jr, Jiang Y. Beta-adrenergic receptor regulation of growth factor protein levels in human choroidal endothelial cells. Growth Factors. 2008;26:325-330.

24. Jiang Y, Walker RJ, Kern TS, Steinle JJ. Application of isoproterenol inhibits diabetic-like changes in the rat retina. Exp Eye Res. 2010; 91:171-179.

25. Jiang Y, Steinle JJ. Systemic propranolol reduces b-wave amplitude in the ERG and increases IGF-1 receptor phosphorylation in rat retina. Invest Ophthalmol Vis Sci. 2010;51:2730-2735.

26. Zheng $\mathrm{Z}$, Chen $\mathrm{H}, \mathrm{Xu} \mathrm{X}$, Li C, Gu Q. Effects of angiotensinconverting enzyme inhibitors and beta-adrenergic blockers on retinal vascular endothelial growth factor expression in rat diabetic retinopathy. Exp Eye Res. 2007;84:745-752.

27. Ricci B, Ricci F, Maggiano N. Oxygen-induced retinopathy in the newborn rat: morphological and immunohistological findings in animals treated with topical timolol maleate. Opbthalmologica. 2000;214:136-139.

28. Storch $\mathrm{CH}$, Hoeger PH. Propranolol for infantile haemangiomas: insights into the molecular mechanisms of action. Br J Dermatol. 2010;163:269-274.

29. Praveen V, Vidavalur R, Rosenkrantz TS, Hussain N. Infantile hemangiomas and retinopathy of prematurity: possible association. Pediatrics. 2009;123:e484-e489.

30. Smith LEH, Wesolowski E, McLellan A, et al. Oxygen-induced retinopathy in the mouse. Invest Opbthalmol Vis Sci. 1994;35: 101-111.

31. Vasilcanu D, Girnita A, Girnita L, Vasilcanu R, Axelson M, Larsson O. The cyclolignan PPP induces activation loop-specific inhibition of tyrosine phosphorylation of the insulin-like growth factor-1 receptor: link to the phosphatidyl inositol-3 kinase/Akt apoptotic pathway. Oncogene. 2004;23:7854-7862.

32. Delafontaine $\mathrm{P}$, Song $\mathrm{YH}$, Li Y. Expression, regulation, and function of IGF-1, IGF-1R, and IGF-1 binding proteins in blood vessels. Arterioscler Thromb Vasc Biol. 2004;24:435-444.

33. Dal Monte M, Ristori C, Cammalleri M, Bagnoli P. Effects of somatostatin analogues on retinal angiogenesis in a mouse model of oxygen-induced retinopathy: involvement of the somatostatin receptor subtype 2. Invest Ophthalmol Vis Sci. 2009;50:3596-3606.

34. Rozen S, Skaletsky H. Primer3 on the WWW for general users and for biologist programmers. Methods Mol Biol. 2000;132:365-386.

35. Wang X, Seed B. A PCR primer bank for quantitative gene expression analysis. Nucleic Acids Res. 2003;31:e154.

36. Pattyn F, Speleman F, De Paepe A, Vandesompele J. RTPrimerDB: the real-time PCR primer and probe database. Nucleic Acids Res. 2003;31:122-123.

37. Livak KJ, Schmittgen TD. Analysis of relative gene expression data using real-time quantitative PCR and the 2(-delta delta C(T)) method. Methods. 2001;25:402-408.

38. Bradford MM. A rapid and sensitive method for the quantitation of microgram quantities of protein utilizing the principle of proteindye binding. Anal Biochem. 1976;72:248-254.

39. Steinle JJ, Zamora DO, Rosenbaum JT, Granger HJ. Beta 3-adrenergic receptors mediate choroidal endothelial cell invasion, proliferation, and cell elongation. Exp Eye Res. 2005;80:83-91.

40. Higgins MD, Yan Y, Schrier BK. Somatostatin analogs inhibit neonatal retinal neovascularization. Exp Eye Res. 2002;74:553-559.

41. Tomasek JJ, Haaksma CJ, Schwartz RJ, et al. Deletion of smooth muscle alpha-actin alters blood-retina barrier permeability and retinal function. Invest Opbthalmol Vis Sci. 2006;47:2693-2700.

42. Schemann M, Hafsi N, Michel K, et al. The $\beta 33$-adrenoceptor agonist GW427353 (Solabegron) decreases excitability of human enteric neurons via release of somatostatin. Gastroenterology. 2010;138:266-274.

43. Vasina V, Abu-Gharbieh E, Barbara G, et al. The $\beta 33$-adrenoceptor agonist SR58611A ameliorates experimental colitis in rats. Neurogastroenterol Motil. 2008;20:1030-1041.
44. Dal Monte M, Cammalleri M, Martini D, Casini G, Bagnoli P. Antiangiogenic role of somatostatin receptor 2 in a model of hypoxia-induced neovascularization in the retina: results from transgenic mice. Invest Ophthalmol Vis Sci. 2007;48:3480-3489.

45. Agostoni P, Palermo P, Contini M. Respiratory effects of betablocker therapy in heart failure. Cardiovasc Drugs Ther. 2009;23: 377-384.

46. Javed U, Deedwania PC. Beta-adrenergic blockers for chronic heart failure. Cardiol Rev. 2009;17:287-292.

47. Ker K, Perel P, Blackhall K. Beta-2 receptor antagonists for traumatic brain injury: a systematic review of controlled trials in animal models. CNS Neurosci Ther. 2009;15:52-64.

48. Sokolis DP, Lampropoulos KM, Dimitriou CA, Balafas E, Boudoulas $\mathrm{H}$, Karayannacos PE. Time-course of mechanical changes of the rat aorta following chronic beta-blocker treatment. Hellenic J Cardiol. 2010;51:19-26.

49. Tsuchida D, Fukuda H, Koda K, Miyazaki M, Pappas TN, Takahashi T. Central effect of mu-opioid agonists on antral motility in conscious rats. Brain Res. 2004;1024:244-250.

50. Yin F, Li P, Zheng M, et al. Interleukin- 6 family of cytokines mediates isoproterenol-induced delayed STAT3 activation in mouse heart. J Biol Chem. 2003;278:21070-21075.

51. Sans V, Dumas de la Roque E, Berge J. Propranolol for severe infantile hemangiomas: follow-up report. Pediatrics. 2009;124; e423-e431.

52. Léauté-Labrèze C, Dumas de la Roque E, Hubiche T, Boralevi F, Thambo JB, Taïeb A. Propranolol for severe hemangiomas of infancy. $N$ Engl J Med. 2008;358:2649-2651.

53. Tolentino MJ. Current molecular understanding and future treatment strategies for pathologic ocular neovascularization. Curr Mol Med. 2009;9:973-981.

54. Witmer AN, Vrensen GF, Van Noorden CJ, Schlingemann RO. Vascular endothelial growth factors and angiogenesis in eye disease. Prog Retin Eye Res. 2003;22:1-29.

55. Schneider C, Krischke G, Keller S, et al. Short-term effects of pharmacologic HIF stabilization on vasoactive and cytotrophic factors in developing mouse brain. Brain Res. 2009;1280:43-51.

56. Lofqvist C, Willett KL, Aspegren O, et al. Quantification and localization of the IGF/insulin system expression in retinal blood vessels and neurons during oxygen-induced retinopathy in mice. Invest Ophthalmol Vis Sci. 2009;50(4):1831-1837.

57. Bergman PB, Moravski CJ, Edmondson SR, et al. Expression of the IGF system in normal and diabetic transgenic (mRen-2)27 rat eye. Invest Opbthalmol Vis Sci. 2005;46:2708-2715.

58. Miura S, Ohno I, Suzuki J, et al. Inhibition of matrix metalloproteinases prevents cardiac hypertrophy induced by beta-adrenergic stimulation in rats. J Cardiovasc Pharmacol. 2003;42:174-181.

59. Chesik D, Wilczak N, De Keyser J. IGF-1 regulates cAMP levels in astrocytes through a beta2-adrenergic receptor-dependant mechanism. Int J Med Sci. 2008;5:240-243.

60. Smith LEH, Shen W, Perruzzi C, et al. Regulation of vascular endothelial growth factor-dependent retinal neovascularization by insulin-like growth factor-1 receptor. Nat Med. 1999;5:1390-1395.

61. Steinle JJ, Smith PG. Role of adrenergic receptors in vascular remodelling of the rat choroid. Br J Pharmacol. 2002;136:730734 .

62. Iaccarino G, Ciccarelli M, Sorriento D, et al. Ischemic neoangiogenesis enhanced by beta2-adrenergic receptor overexpression: a novel role for the endothelial adrenergic system. Circ Res. 2005; 97:1182-1189.

63. Annabi B, Lachambre MP, Plouffe K, Moumdjian R, Béliveau R. Propranolol adrenergic blockade inhibits human brain endothelial cells tubulogenesis and matrix metalloproteinase-9 secretion. Pharmacol Res. 2009;60:438-445.

64. Jorge R, Oyamaguchi EK, Cardillo JA, Gobbi A, Laicine EM, Haddad A. Intravitreal injection of dispase causes retinal hemorrhages in rabbit and human eyes. Curr Eye Res. 2003;26:107-112.

65. Lashbrook BL, Steinle JJ. Beta-adrenergic receptor regulation of pigment epithelial-derived factor expression in rat retina. Auton Neurosci. 2005;121:33-39.

66. Mori A, Miwa T, Sakamoto K, Nakahara T, Ishii K. Pharmacological evidence for the presence of functional beta(3)-adrenoceptors in 
rat retinal blood vessels. Naunyn Schmiedebergs Arch Pharmacol. 2010;382:119-126.

67. Guan Y, Gao L, Ma HJ, et al. Chronic intermittent hypobaric hypoxia decreases beta-adrenoceptor activity in right ventricular papillary muscle. Am J Physiol Heart Circ Physiol. 2010;298:H1267-H1272.

68. Baloğlu E, Ke A, Abu-Taha IH, Bärtsch P, Mairbäurl H. In vitro hypoxia impairs beta2-adrenergic receptor signaling in primary rat alveolar epithelial cells. Am J Physiol Lung Cell Mol Physiol. 2009;296:L500 -L509.

69. Pournaras CJ, Rungger-Brändle E, Riva CE, Hardarson SH, Stefansson E. Regulation of retinal blood flow in health and disease. Prog Retin Eye Res. 2008;27:284-330.
70. Phipps JA, Wilkinson-Berka JL, Fletcher EL. Retinal dysfunction in diabetic ren-2 rats is ameliorated by treatment with valsartan but not atenolol. Invest Ophthalmol Vis Sci. 2007;48:927-934.

71. Wilkinson-Berka JL, Tan G, Jaworski K, Ninkovic S. Valsartan but not atenolol improves vascular pathology in diabetic Ren-2 rat retina. Am J Hypertens. 2007;20:423-430.

72. Shyu KG, Liou JY, Wang BW, Fang WJ, Chang H. Carvedilol prevents cardiac hypertrophy and overexpression of hypoxiainducible factor-1alpha and vascular endothelial growth factor in pressure-overloaded rat heart. J Biomed Sci. 2005;12:409420 . 